DERMOT GATELY

New York University

\title{
Lessons from the 1986 Oil Price Collapse
}

IN the first half of 1986 crude oil prices fell to about $\$ 12$ a barrel, back to their level of 1974 and, when adjusted for changes in the general price level, close to the real oil price that prevailed in 1973 just before the first OPEC price increase. This paper reviews the 1986 oil price collapse, discusses why it came as a surprise, and assesses what it means for oil prices in 1986-87 and beyond.

The first section of the balance of the paper presents an overview of the 1970-86 world oil market: price, demand and supply by region, and output and revenue for OPEC. The next section reviews the record of expert opinion since the first big price increases in 1973-74, paying special attention to the 1980-81 World Oil study by the Energy Modeling Forum (EMF) and to the results from a series of polls of energy analysts since 1981 by the International Energy Workshop. The third section presents an explanation of the 1986 price collapse, together with a simulation of the choices facing OPEC for 1986 and thereafter. The fourth section examines the question of what should have been expected for 1985-86, going as far back as 1980 . Included there are econometric estimates of oil demand functions for the United States and five other countries of the Organization for Economic Cooperation and Development (OECD). The paper concludes with a discussion of the outlook for the world oil market.

The conclusions of the paper are briefly as follows. The 1986 price collapse was the result of a decision by Saudi Arabia and some of its neighbors to increase their share of the oil market. Unlike other produc-

The author is grateful for helpful comments from Alan Manne and members of the Brookings Panel. 
ers, they did not suffer great revenue losses, because the price declines were offset by their output increases. But with oil prices as low as $\$ 12$ a barrel, their revenue would also decline, so that they can be expected to restrict output at that price, even unilaterally. I expect, therefore, that OPEC's August 1986 agreement in Geneva to restrict output will be successful. By no means does the 1986 price collapse represent the death of OPEC, as has often been proclaimed.

Over the next two decades, price can be expected to increase substantially, although OPEC will continue to have difficulty restricting output if it raises price too far above what is warranted by market conditions. The world's oil resources are still heavily concentrated in the Persian Gulf, and there is no alternative energy source now on the horizon that is cheap, clean, and plentiful. With continuing world economic growth eventually outweighing the demand-reducing adjustment to the 1973-74 and 1979-80 price increases, and with limited prospects for continuing expansion of non-OPEC production, the demand for OPEC oil will grow substantially, and OPEC will respond by raising the price. But OPEC, especially Saudi Arabia and its allies, will probably be cautious in the future about abrupt price increases, having seen the consequences during 1980-86.

In the event of a major disruption, however, price could go up sharply, and the West will be only slightly less vulnerable than it was in 1979-80. Although the resulting price increase need not be permanent, it would again have a substantial negative effect on the world economy.

\section{Overview of the Data}

In 1973-74 the real price of crude oil more than tripled. ${ }^{1}$ After declining slightly in $1975-78$, it doubled again in $1979-80$. But the $1979-80$ price increase was eroded between 1981 and 1985, as price declined by nearly 40 percent. Price then collapsed in the first half of 1986, falling by more than 50 percent. Within the past five years, the real price of oil has fallen from more than a fivefold multiple of its 1970 value to less than a twofold multiple.

As illustrated in figure 1, the world demand for oil, which had grown

1. See U.S. Department of Energy, Energy Information Administration, Annual Review of Energy 1985, DOE/EIA-0384(85) (DOE, 1985), p. 135. 
Figure 1. World Oil Demand, by Region, 1970-85

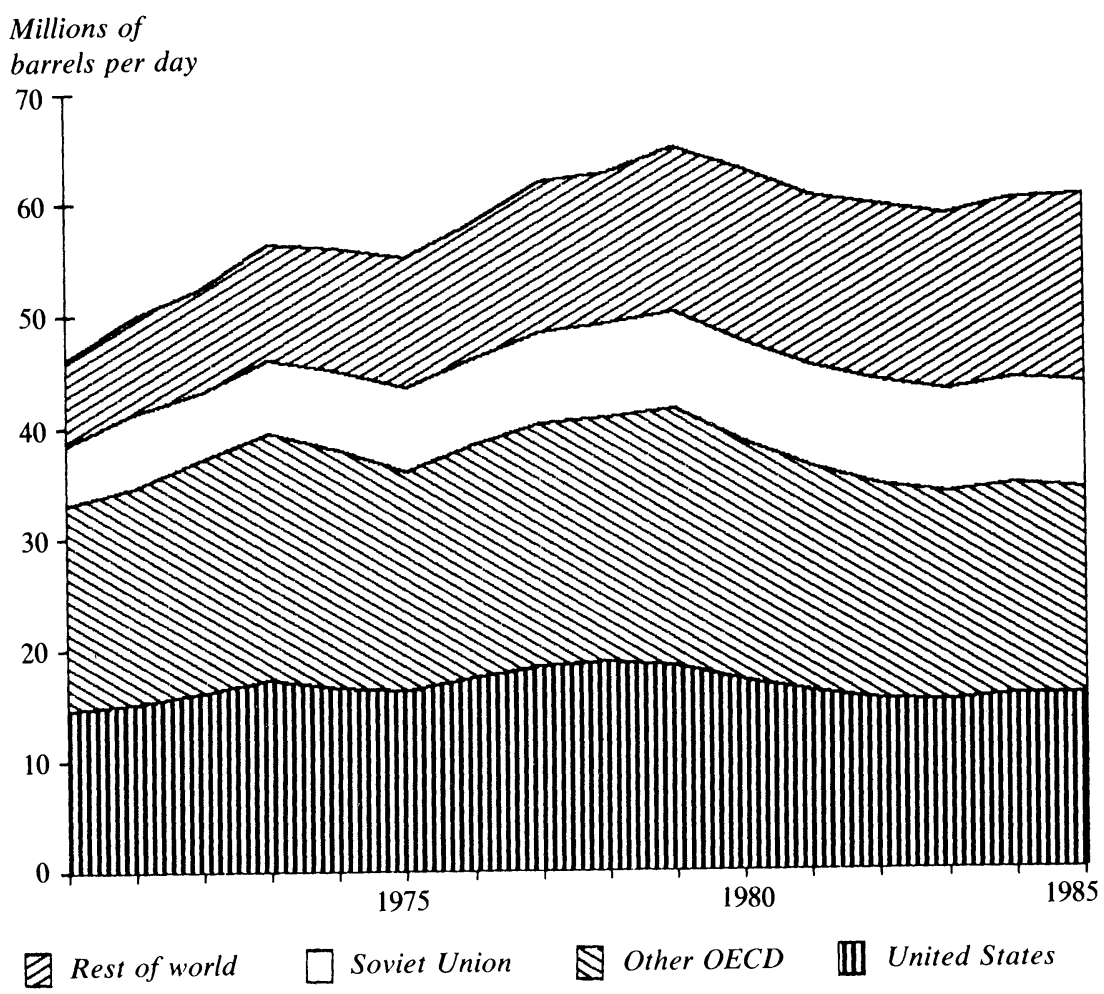

Sources: U.S. Department of Energy, Energy Information Administration, Annual Energy Review 1985, DOE/ ElA-0384(85) (DOE, 1985) p. 239; and DOE, Monthly Energy Review, various issues.

rapidly before the 1973-74 price increase, grew much less rapidly during 1973-78. It then fell by about 10 percent during 1979-83 and has grown only slightly since. The OECD had both the biggest demand growth before 1973 and the biggest declines after the two price increases. Demand in the Soviet Union and in the rest of the world also increased rapidly before 1973 and has continued to increase since, although at a slower pace.

Figure 2 shows regional changes in world oil production since 1970. Until 1976 the non-OPEC oil supply grew quite slowly. Since 1977 there have been substantial increases from Mexico, the North Sea, and a large number of small producers. ${ }^{2}$ The 16 percent decrease in U.S. output

2. Between 1979 and 1985 five non-OPEC developing countries (Brazil, Egypt, India, Malaysia, and Oman) doubled their output, to a total of 3 million barrels per day. 
Figure 2. World Oil Production, by Region, 1970-86

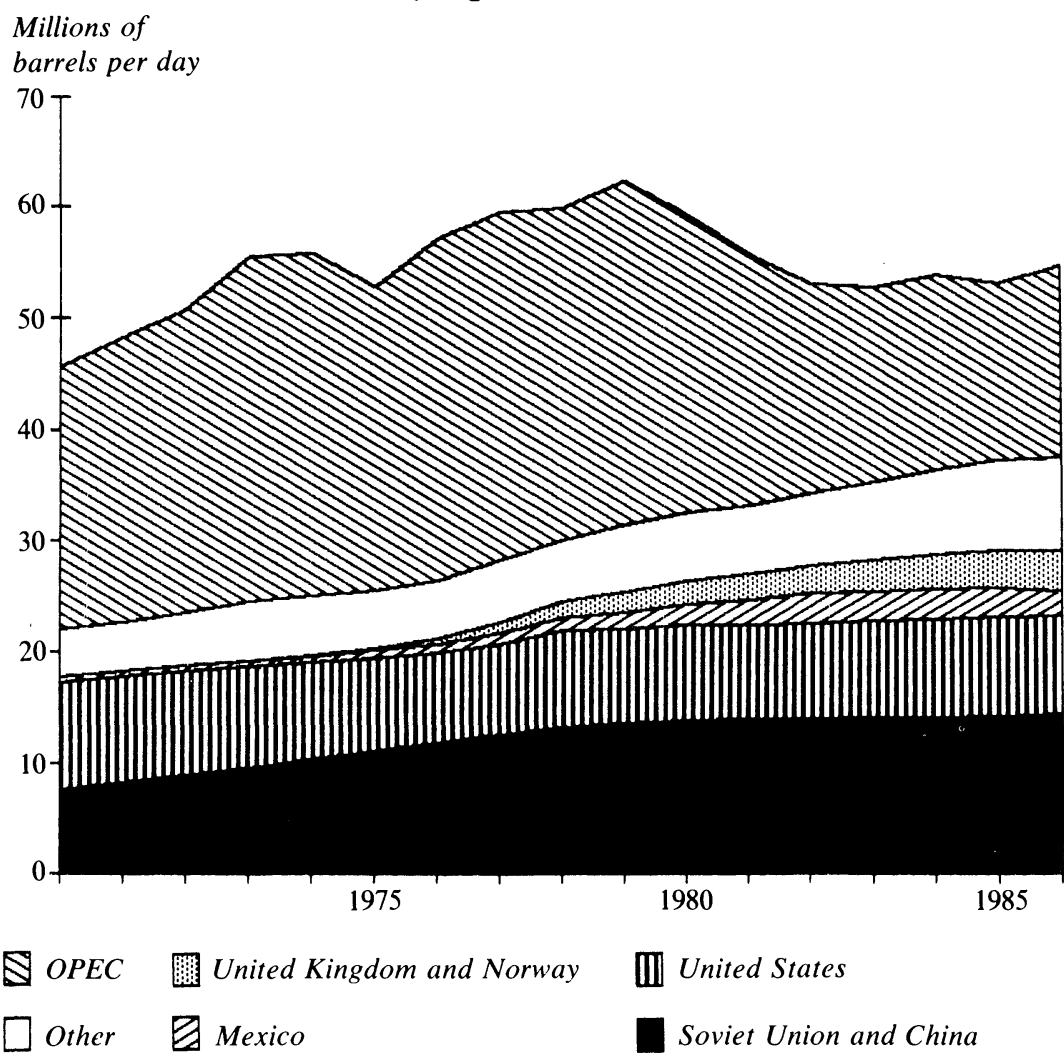

Sources: DOE, Annual Energy Review 1985, p. 235; and DOE, Monthly Energy Review, various issues. Average for 1986 is based on data through May.

during 1970-76 was halted by an increase in Alaskan production starting in 1977. But total U.S. output in 1985 was still around 7 percent below its 1970 peak, despite much higher prices; without Alaska, U.S. output would have been 25 percent lower in 1985 than in 1970.

OPEC, as the price-setting residual supplier, has had to reduce its output to support a given price level. It has seen the demand for its oil fall by nearly 40 percent between 1979 and 1982 and remain low since. The changes in output within OPEC from 1970 to 1986 are depicted in figure $3 .{ }^{3}$ Virtually all OPEC members shared in the burden of output

3. To simplify the graphs, I present country results only for Saudi Arabia, Iran, and Iraq; the other OPEC members are grouped as follows. Kuwait, the United Arab Emirates 
Figure 3. OPEC Output Levels, 1970-86

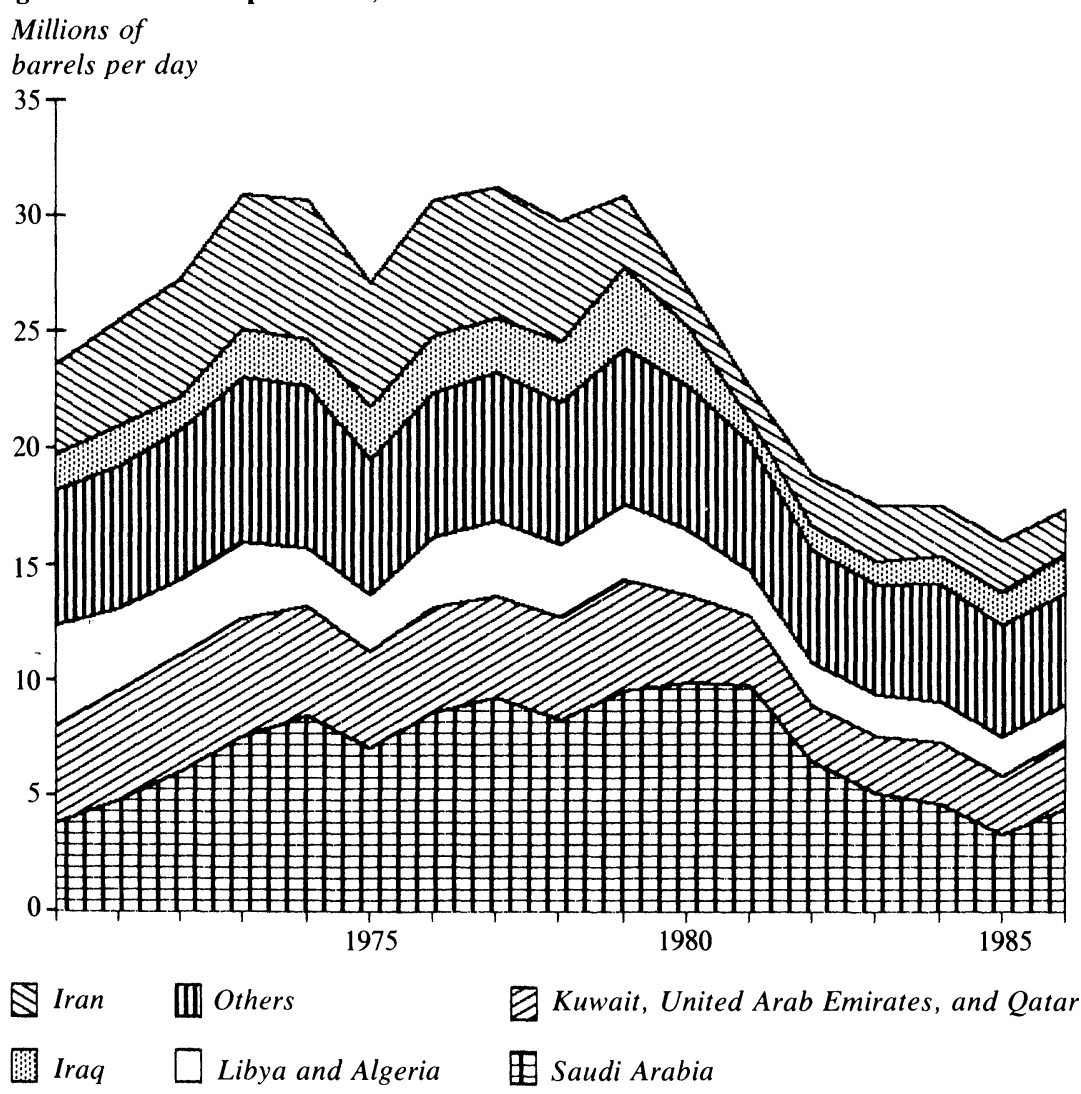

Sources: DOE, Annual Energy Review 1985, p. 235; and DOE, Monthly Energy Review, various issues. Average for 1986 is based on data through May.

restriction from 1979 to 1985 : each cut output at least 20 percent. But the greatest percentage cutbacks were borne by Saudi Arabia (more than 60 percent of its 1979 level), Kuwait (almost 60 percent), and Libya (almost 50 percent). Iraq and Iran are special cases, given their warrelated output reductions. But since their minimum output levels in 1981-82, both have been increasing their output slightly and thus their

(UAE), and Qatar are immediate neighbors of Saudi Arabia and have usually followed similar policies. Libya and Algeria are North African producers who have often pushed for higher prices and have restricted output when necessary. The "Others" include Indonesia, Nigeria, Venezuela, and two small producers, Ecuador and Gabon; this group has been least willing to restrict output. The 1986 figures are averages through May. 
share of OPEC output significantly. From August 1985 through mid1986, OPEC output increased by about 4 million barrels per day (bpd), or about 25 percent. More than half the increase came from Saudi Arabia, but some other members also had significant increases, especially Kuwait, the United Arab Emirates (UAE), Iraq, and Nigeria. In the face of the price collapse, Iran and Mexico (a non-OPEC producer) cut output.

The sharp declines in OPEC output since 1980, together with significant real price declines, have resulted in a dramatic drop in OPEC revenue, as depicted in figure 4. During 1983-85 OPEC revenue was below its level in the mid-1970s and less than half what it had been in 1980-81. After prices collapsed in 1986, OPEC revenue fell further, to only slightly above its pre-1973 levels. In the short run, therefore, the demand for OPEC oil is still inelastic. Within OPEC, Saudi Arabia and Kuwait experienced the sharpest revenue declines during 1981-85, as they had the largest output cutbacks.

Figure 5 illustrates trends in price, output, and revenue for both Saudi Arabia and OPEC as a whole, from 1970 to 1986. Among other things, it shows clearly the differing revenue impact of the 1985-86 price declines. For Saudi Arabia, revenue has declined only slightly: the 50 percent price declines were almost offset by increased output. But, for OPEC as a whole, revenue has declined sharply.

Although OPEC's share of world oil production has declined since 1973 to less than 30 percent, its share of the world's oil reserves has remained roughly constant, at about two-thirds of the total. ${ }^{4}$ Despite an enormous amount of exploration, the only substantial non-OPEC discoveries since 1973 have been in Mexico, whose share of world reserves is now about 10 percent. (North Sea and Alaskan oil had been discovered in the late 1960s and is only a small part of the world's total reserves.) Oil production since 1970 has exceeded discoveries, mostly because of the sharp decline in discoveries within the Middle East. ${ }^{5}$ The oil reserves

4. For both proved reserves and estimated undiscovered reserves, see Department of Energy, Energy Information Administration, International Energy Outlook 1985, with Projections to 1995, DOE/EIA-0484 (85) (DOE, 1985), table 3, p. 12.

5. See Exxon Corporation, World Energy Outlook (Exxon Background Series, December 1980), p. 24. The decline could be a consequence of those countries having little incentive to explore further, given their already huge reserves. But more likely the largest fields are discovered relatively early in the history of a given oil province. See Gordon M. Kaufman, Statistical Decision and Related Techniques in Oil and Gas Exploration (Prentice Hall, 1962); “'Oil and Gas: Estimation of Undiscovered Resources," in M. A. 
Figure 4. OPEC Revenue Levels, 1970-86 ${ }^{\mathrm{a}}$

Millions of

dollars per day

(1982 dollars)

1200

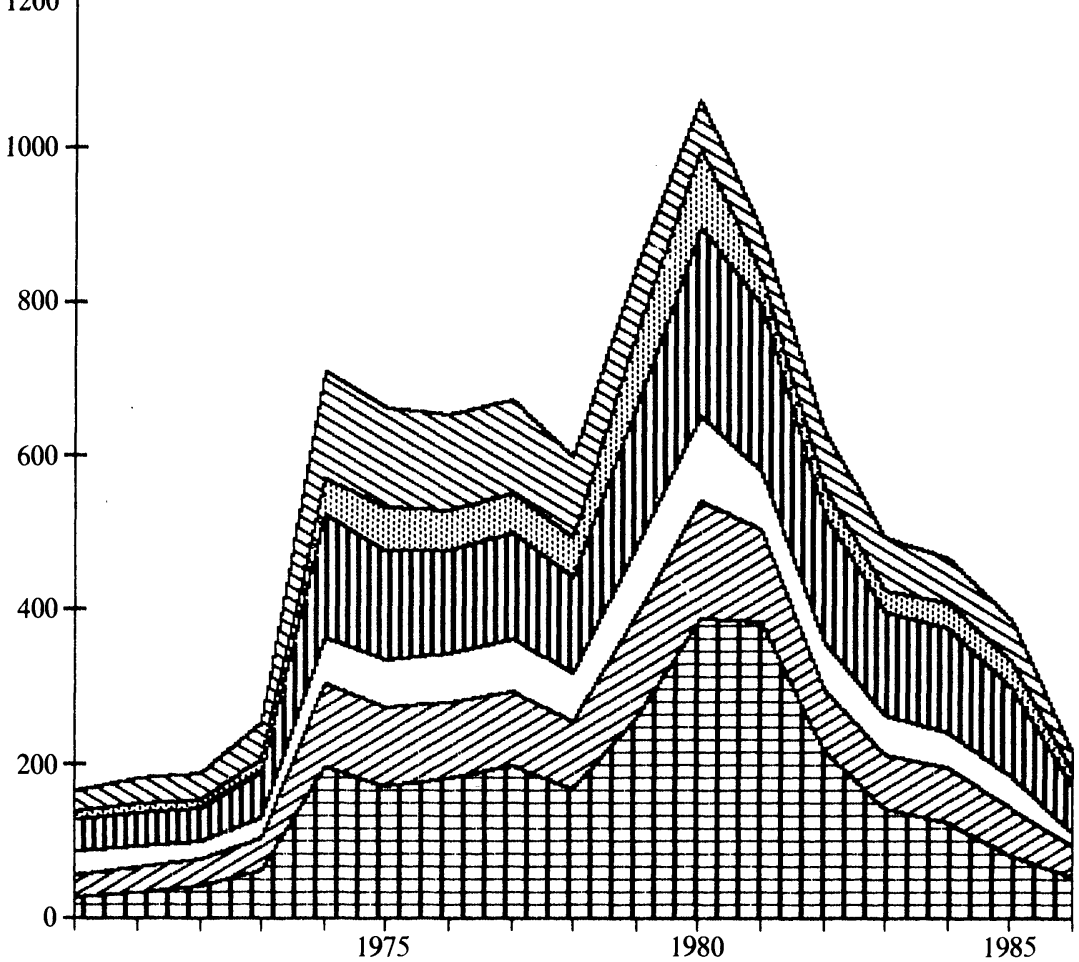

Iran IIII Others

Kuwait, United Arab Emirates, and Qatar

Iraq

$\square$ Libya and Algeria

里 Saudi Arabia

Sources: Output levels from figure 3; price from DOE, Annual Energy Review 1985, p. 135, and DOE, Monthly Energy Review, various issues. Average for 1986 is based on data through May.

a. Product of the real U.S. price of imported crude oil and OPEC production levels.

of the United States, Canada, and the North Sea would be exhausted after about three decades of production at 1985 levels. Most Persian Gulf producers, on the other hand, could sustain 1985 output levels for more than a century.

Adelman and others, Energy Resources in an Uncertain Future (Ballinger, 1983); and R. Nehring, "Prospects for Conventional World Oil Resources," in Jack M. Hollander, Harvey Brooks, and Melvin K. Simmons, eds., Annual Review of Energy, vol. 7 (1982), pp. 175-200. 
Figure 5. Price, Output, and Revenue Comparison, Saudi Arabia and OPEC, 1970-86

\section{Dollars}

a barrel

(1982 dollars)

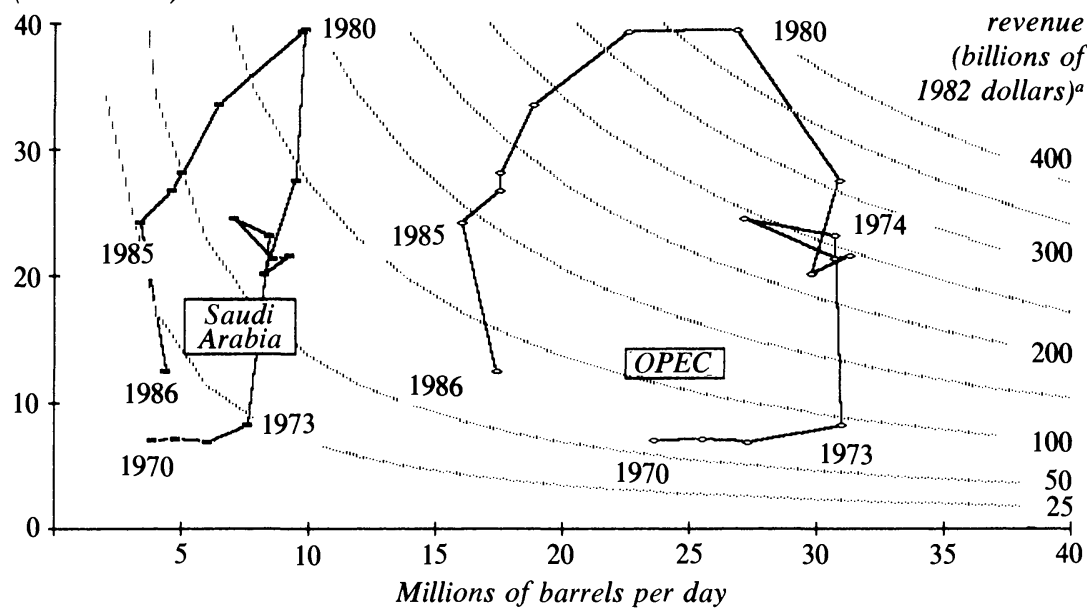

Sources: Output levels from figure 3. Price from DOE Annual Energy Review 1985, p. 135; and DOE, Monthly Energy Review, various issues. Data for 1986 based on average through May.

a. Each curved line is an isoquant along which revenue is constant at the indicated levels.

\section{Review of Expert Opinion, 1973-85}

When oil prices collapsed in 1986, it was not the first time that the world oil market had surprised most observers. It is instructive to review how well the experts have kept pace with the market since $1973 .^{6}$

\section{ANALYSES DURING 1973-78}

In 1973-74 many experts believed that OPEC had blundered by raising its price to an unsustainably high level and that it was pricing itself out of the market. Milton Friedman presented an extreme version of this view in March 1974: "In order to keep prices up, the Arabs would have to curtail their output by ever larger amounts. But even if they cut their output to zero, they could not for long keep the world price of crude at $\$ 10.00$ a barrel." 7

6. Other surveys of this literature can be found in Dermot Gately, "A Ten-Year Retrospective: OPEC and the World Oil Market,' Journal of Economic Literature, vol. 22 (September 1984), pp. 1100-14; and James M. Griffin and David J. Teece, eds., OPEC Behavior and World Oil Prices (London: George Allen and Unwin, 1982).

7. Newsweek (March 4, 1974), p. 71. 
Yet, as the analytic work of 1974-75 appeared, much of it concluded that the pre-1973 price had been unsustainably low. But, overestimating both the adjustment speed of demand and the increase in non-OPEC supply in response to higher prices, it also concluded that the 1975 price was too high for OPEC's long-run interest and that some downward adjustment would be necessary. ${ }^{8}$

In 1976-78, the demand for OPEC oil recovered from its 1974-75 decline. There had been little non-OPEC supply response to higher prices, and world oil demand had resumed its growth, although at a diminished rate. Most observers had come to view the 1973-74 price increase as sustainable, but as a one-time event, corresponding to OPEC's successful cartelization of the world oil market. Henceforth, price was expected to rise only gradually, up to the "backstop" cost of alternative energy sources. ${ }^{9}$ But some analysts, most notably the Workshop on Alternative Energy Strategies (WAES), argued in 1977-78 that price was unsustainably low. They concluded that if the real price were held constant through the 1980 s, projected oil demand would exceed the likely supply. ${ }^{10}$

8. The seven models available in 1974-75 were reviewed in Dietrich Fischer, Dermot Gately, and John F. Kyle, "The Prospects for OPEC: a Critical Survey of Models of the World Oil Market," Journal of Development Economics, vol. 2 (December 1975), pp. 363-86. The models were those of Charles Blitzer, Alex Meeraus, and Ardy Stoutjesdijk, "A Dynamic Model of OPEC Trade and Production," Journal of Development Economics, vol. 2 (December 1975), pp. 319-35; Douglas R. Bohi and Milton Russell, U.S. Energy Policy (Resources for the Future, Johns Hopkins University Press, 1975); U.S. Federal Energy Administration, Project Independence Report (Government Printing Office, 1974); Michael Kennedy, "An Economic Model of the World Oil Market," Bell Journal of Economics and Management Science, vol. 5 (Autumn 1974), pp. 540-77; Basil A. Kalyman, "Economic Incentives in OPEC Oil Pricing Policy," Journal of Development Economics, vol. 2 (December 1975), pp. 337-62; W. J. Levy, "Implications of World Oil Austerity" (30 Rockefeller Plaza, New York, N.Y.); and William D. Nordhaus, "The Allocation of Energy Resources," BPEA, 3:1973, pp. 529-70.

9. Price was expected to stay below the backstop cost, the cost of alternatives to conventional oil, such as shale oil, tar sands, or coal liquifaction. Unfortunately, it was rarely noted that the backstop cost could be an upper limit only in the long run, when there would be sufficient time to expand capacity. This could be three decades, or more. In the meantime, OPEC's price could well rise above the backstop cost. Furthermore, estimates of the cost of these alternatives increased dramatically in the late 1970s as more was learned about their technical characteristics. In World Oil a cost of $\$ 60$ a barrel (in 1981 dollars) was used for the backstop, which was also assumed to be capacity-constrained through 2010. Not surprisingly, the price projections rose above the backstop cost, before coming down again when backstop capacity expanded. See Energy Modeling Forum, World Oil, EMF Report 6, Summary Report (Stanford, Calif.: EMF, February 1982).

10. Workshop on Alternative Energy Strategies, Energy: Global Prospects, 1985- 
In a 1978 survey, I drew the following conclusions:

Having reviewed nearly two dozen models and analyses of OPEC and energy markets, what can be said about the 1980's? Briefly, the status quo through the early-to-mid 1980's, with a tightening world oil market possible thereafter.

In the coming five years [1979-1984] virtually all analyses project a continuation of current market conditions in the world oil market. . . . But we do not expect substantial changes in real prices, either down or up, given the stabilizing position of Saudi Arabia and its Arab allies on the Persian Gulf.

The outlook beyond 1985, however, remains very uncertain. Many forecast a continuation of current market conditions for the entire decade. Many others project increased tightening of the world oil market."

\section{ANALYSES DURING 1979-81 AND THE EMF WORLD OIL STUDY}

The abrupt $1979-80$ price doubling clearly came as a surprise. Few observers had anticipated another price increase, especially one so large. In less than a decade, OPEC had increased the real price fivefold. These were heady times for OPEC, as Fereidun Fesharaki wrote in 1981, "As to the extent of the price increases [ in the 1980s], one can only say with certainty that real prices will not be allowed to decline again. . . . On the price front, price unity seems to have permanently disappeared. OPEC feels no need for it anymore. . . . Real prices are expected to rise by three to ten percent per annum during the 1980's, at irregular intervals. $" 12$

It now seems clear that OPEC overshot the mark with its 1979-80 price doubling. Groping for an "optimal" price, OPEC misinterpreted the spot market price as a good indicator of a long-term equilibrium price. It raised its contract price too much and too rapidly.${ }^{13}$ In particular, the Saudis must regret their decision of January 20, 1979, to cut output during the height of the Iranian revolution. ${ }^{14}$

2000 (McGraw-Hill, 1977). WAES assumed high economic growth rates. The high- and low-growth assumptions were, respectively, 6 percent and 3.5 percent.

11. Dermot Gately, "The Prospects for OPEC Five Years after 1973-74," European Economic Review, vol. 12 (October 1979), p. 378.

12. Fereidun Fesharaki, "World Oil Availability: The Role of OPEC Policies, ' in Jack M. Hollander, Melvin K. Simmons, and David O. Wood, eds., Annual Review of Energy, vol. 6(1981), pp. 304, 306, 307.

13. For a description of OPEC determining its contract price as a function of recent spot market prices, see Philip K. Verleger, Jr., Oil Markets in Turmoil: An Economic Analysis (Ballinger, 1982).

14. M. A. Adelman, "OPEC as a Cartel," in Griffin and Teece, OPEC Behavior and World Oil Prices, pp. 37-63. 
During 1980-81, the Energy Modeling Forum (EMF) of Stanford University conducted a controlled comparison of ten prominent models of the international oil market. ${ }^{15}$ Most of the models were simulation models, in which OPEC set price according to some target-capacityutilization pricing rule. In only one of the models did OPEC act as an intertemporal wealth-maximizing price-setter. ${ }^{16}$ In one model OPEC capacity was endogenous; the rest assumed that OPEC capacity was constant at 34 million bpd. In all models OPEC acted as the residual supplier, producing the difference between world oil demand and nonOPEC supply.

The EMF study remains one of the most useful pieces of work in this area. It made standardized assumptions for a variety of parameter values, such as economic growth rates, the size of the resource base for conventional oil, the cost of alternative energy sources, OPEC capacity, and the responsiveness of oil demand to changes in price and in economic growth. For each of twelve "scenarios" (each defined by a given set of assumptions about the world oil market), the models generated their respective projections.

The study's long-run conclusions about world oil prices were fairly pessimistic: in none of the models under any of the scenarios were world oil prices lower in the year 2000 than they were in 1980; in most, prices were considerably higher. As the final report concluded, "While there remains a high degree of uncertainty about future world oil prices, our analysis suggests that most of this uncertainty concerns not whether real prices will rise during the next several decades but rather how rapidly they will rise. . . . We expect a soft oil market during the first half of the decade unless another supply disruption occurs, but by 1990 real prices

15. Included were two models from the Department of Energy (WOIL and IEES/ OMS), three from universities (Choucri's IPE, Gately-Kyle-Fischer, and Manne's ETAMACRO), and others from various institutions (British Petroleum, Kennedy-Nehring, Salant-ICF, Ervik's OILTANK, and OILMAR). Several are available commercially. See Energy Modeling Forum, World Oil, and EMF, "World Oil Graphics" (EMF, 1982). For separate descriptions of the Choucri, Gately-Kyle-Fischer, Manne, and Salant models, see Nazli Choucri, International Energy Futures (MIT Press, 1981); Dermot Gately and John F. Kyle, in association with Dietrich Fischer, "Strategies for OPEC's Pricing Decisions," European Economic Review, vol. 10 (November 1977), pp. 209-30; Alan S. Manne, "ETA-MACRO: A Model of Energy-Economy Interactions,' in Charles J. Hitch, ed., Modeling Energy-Economy Interactions: Five Approaches (Washington, D.C.: Resources for the Future, 1977), pp. 1-45; and Stephen W. Salant, Imperfect Competition in the World Oil Market (D.C. Heath, 1982).

16. Salant, Imperfect Competition. 
can be expected to exceed their current high levels." ${ }^{17}$ But even with a large number of standardized parameter assumptions, the range of price projections from different models for a given scenario is striking. For a typical scenario, the range of prices projected for the year 2000 was between $\$ 40$ a barrel and $\$ 80$ a barrel (in 1981 dollars).

The accuracy of the EMF study's short-term projections can be evaluated by comparing the projections for $1980-85$ with actual prices, output, and demand. The appropriate EMF scenario is the low economic growth scenario, which assumed annual growth rates of about 2.3 percent. ${ }^{18}$ Of the ten models only Choucri's projected declines in the demand for OPEC oil comparable to the actual 12 million bpd drop. While a few models projected declines in world oil demand comparable to the actual decline of 5-7 million bpd, only Choucri also projected significant non-OPEC oil production increases. Most of the models projected constant or increasing prices. Only three of the ten models projected price declines, and all three predictions were less than half the actual decline through $1985 .{ }^{19}$

Virtually all the EMF models underestimated the declining demand for OPEC oil during 1980-85. All but one of the models were too pessimistic about the near-term possibilities for increasing non-OPEC production: even with constant or higher prices, few models showed increases. ${ }^{20}$ Misjudgments by individual modelers about non-OPEC supply increases were compounded by underestimates in the EMF standardized assumptions about price-responsiveness of world oil demand and about the amount of lagged responsiveness to the 1973-74 price increases still to come.

But the failure of the EMF models to project declining prices during

17. EMF, World Oil, pp. 2-3.

18. Even the 2.3 percent annual growth rate is higher than the actual 2.1 percent growth rate for the OECD and 1.6 percent rate for non-OECD countries; see Shell Briefing Service, The World Oil Scene and OPEC (London: Shell International Company, Ltd., 1986).

19. Choucri, Gately-Kyle-Fischer, and the Department of Energy's IEES/OMS.

20. Some industry analysts projected non-OPEC supply increases by 1985 , but not as great as the 15 percent increase over 1980 that did occur, even in the face of real price declines. For example, Exxon had projected that non-OPEC supply would be 15 percent higher in 1990 than in 1979 (Exxon, World Energy Outlook). And John Lichtblau in 1981 projected a 24 percent increase by 1990 and 13 percent by 1985 (compared with 1980 output); see "The Limitation to OPEC's Pricing Policy," in Griffin and Teece, OPEC Behavior and World Oil Prices, pp. 131-44. 
the early 1980s does not mean that their projections of substantially higher prices by the year 2000 can be brushed aside. Those projections resulted mostly from increases expected during the 1990s. By that time, world oil demand was expected to grow more rapidly, as demandincreasing economic growth eventually overtook the demand-reducing adjustment to the two major price increases. With limited prospects for continuing expansion of non-OPEC production, the demand for OPEC oil was expected to grow substantially and OPEC was expected to respond by raising the price. Although actual price is lower in 1986 than anticipated in 1980 or even 1985 , that fundamental dynamic is even more relevant now, because the 1980-86 price declines have tempered the demand-reducing effects of the 1979-80 price increases.

\section{INTERNATIONAL ENERGY WORKSHOP POLLS}

The best summary of recent energy projections can be found in the polls by the International Energy Workshop (IEW), as described by Alan Manne and Leo Schrattenholzer. ${ }^{21}$ These polls, conducted annually since 1981 and covering energy prices and quantities over the next twenty-five years, survey some eighty organizations, analysts, and modeling groups located throughout the world.

Price projections in the polls have changed significantly since 1981. As figure 6 shows, between the 1981 and 1986 polls, the median projections of crude oil prices for the year 2000 fell as sharply as did actual prices in the years 1981-86. ${ }^{22}$ Such a sharp downward revision of price projections seems unsupported by the underlying demand and supply situation over the longer term. It appears to be a case of overcompensating for current market conditions.

According to the median projection in the 1985 poll, total world oil demand is projected to grow relatively slowly through the year 2000 , at

21. Alan S. Manne and Leo Schrattenholzer, "International Energy Workshop: A Progress Report" (International Energy Workshop, Stanford, California, July 1985); "International Energy Workshop: Summary of Poll Responses" (IEW, July 1985); "International Energy Workshop: Oil Price Projections" (IEW, 1986), forthcoming in Energy Journal; and "International Energy Workshop: Overview of Poll Responses" (IEW, July 1986).

22. Although the group of respondents varies somewhat from one year to another, the poll's authors argue that the variation cannot explain the dramatic revision of projected prices. 
Figure 6. Oil Prices, 1970-86, and Successive Price Projections, 1990-2010

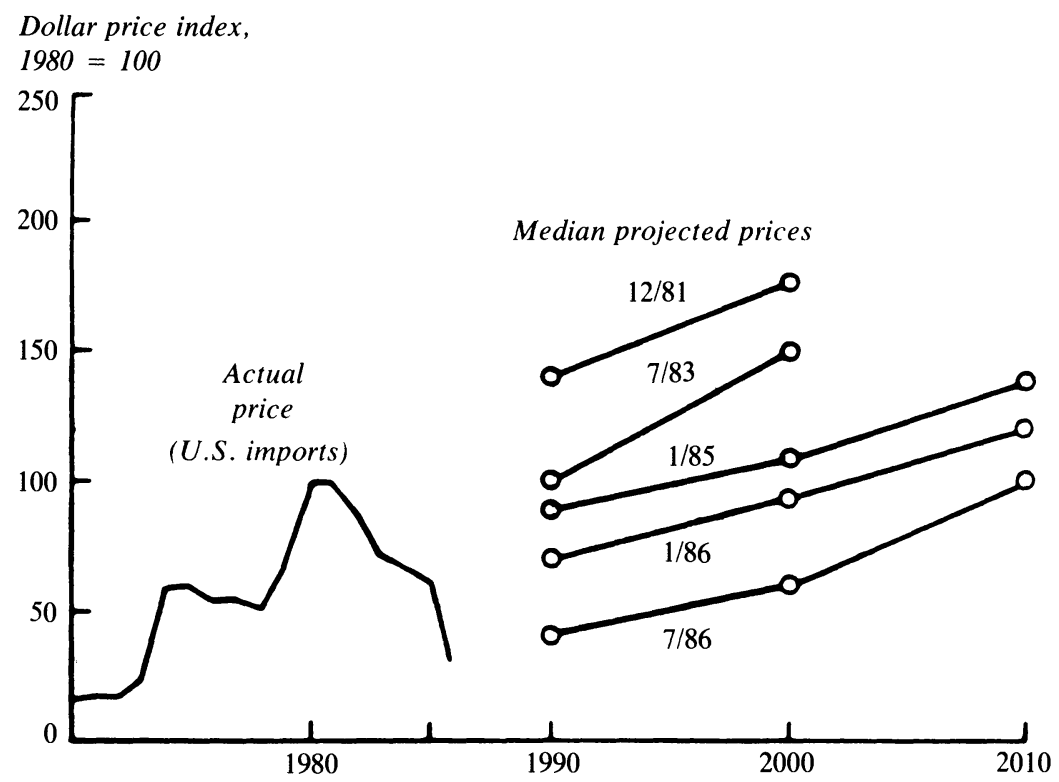

Sources: Alan S. Manne and Leo Schrattenholzer, "International Energy Workshop: A Progress Report" (International Energy Workshop, Stanford, Calif., July 1985); "International Energy Workshop: Summary of Poll Responses"” (IEW, July 1985); "International Energy Workshop: Oil Price Projections," (IEW, 1986), forthcoming in Energy Journal; and "International Energy Workshop: Overview of Poll Responses" (IEW, July 1986).

an annual rate of 0.7 percent. Within the developing countries, demand is projected to continue to grow at a moderate rate. But it is expected to grow very slowly in the centrally planned economies and to decline slightly in the OECD. The region with the widest range of oil demand projections is non-OPEC developing countries. Output in the centrally planned economies and in the OECD is expected to be fairly flat. Declines in U.S. output would be offset by increases elsewhere in the OECD. In the non-OPEC developing countries output is expected to double, although there is a wide range of projections, which suggests uncertainty about their resource base. The residual supplier will continue to be OPEC, whose production is expected to increase significantly by 2000 , to slightly above its 1980 value of some 30 million bpd, or 50 percent higher than its 1985 output level. There is also a wide range of projections for OPEC output, but the uncertainty is about their price and output decisions, rather than about their resource base. 


\section{HOGAN AND LEIBY PROJECTIONS}

Any projection involving many assumptions about parameter values and model structure will necessarily result not in a single value but in a range of possible values. This unavoidable uncertainty is nicely illustrated in figure 7, drawn from the work of William Hogan and Paul Leiby, which shows oil price projections for 1987, 1990, 1995, and 2000, made under a variety of assumptions about whether a disruption occurs in a given year and about certain parameter values such as demand elasticities, the capacity of OPEC and its target level of capacity utilization, and exchange rates. ${ }^{23}$

The price distributions depict the range of uncertainty for oil prices as a function of the assumptions made. ${ }^{24}$ The lower ends of the price distributions for 1987 and 1990 are not much below the 1985 price level; the upper tails stretch quite high. The asymmetry results from the omission of such assumptions as a complete OPEC collapse or a large and sudden output increase, such as occurred in 1985-86. Also, the assumed OPEC pricing function responds asymmetrically, depending upon whether OPEC output is above or below the target levels of capacity utilization: price would be increased more rapidly if output were above the target than it would be cut if output were below the target.

\section{Understanding the 1986 Price Collapse}

Early in 1986, after years of futile attempts to get its OPEC partners to observe their production quotas and share the burden of output restriction more equitably, Saudi Arabia and its allies undertook to produce their "fair share" and let price fall as a consequence. ${ }^{25}$ The dire

23. William W. Hogan and Paul N. Leiby, "Oil Market Risk Analysis," Report of the Harvard Energy Security Project (Harvard University, John F. Kennedy School of Government, December 1985).

24. The distribution is sawtoothed, rather than smooth, because a relatively small number of parameter cases were considered. As the number and variety of cases increased, the distribution would become smoother.

25. There is no conclusive evidence to support the view that inventories were destabilizing during the price collapse. (In 1979-80, during the Iranian revolution, oil 


\section{Figure 7. Risk Analysis Projections of World Oil Prices ${ }^{a}$}

\section{Dollars a}

barrel (1984 dollars)

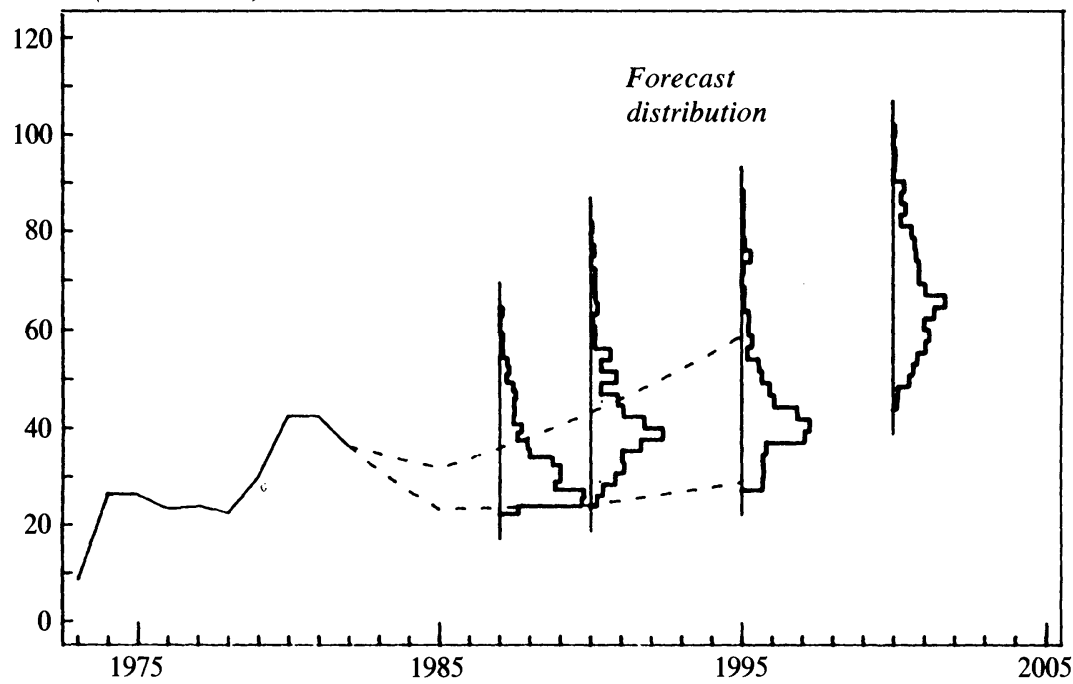

Sources: William W. Hogan and Paul N. Leiby, "Oil Market Risk Analysis," Report of the Harvard Energy Security Project (Harvard University, John F. Kennedy School of Government, December 1985).

a. Alternative oil price forecasts under varying assumptions of demand elasticities, OPEC capacity, its target level of capacity, and exchange rates for non-U.S. demand regions.

future about which the Saudis had warned their partners became a dire reality. Although the revenue of the Saudis has been relatively unaffected by the price decreases, the revenue of other OPEC members has been greatly reduced.

As long as the price cuts are not carried too far, they offer longerterm benefits for Saudi revenue and for the credibility of any future Saudi threats to increase output. Because of the Saudis' huge oil reserves, they

inventories were built up at the rate of 1-2 million bpd. This aggravated the market tightness and drove spot prices and contract prices higher than they would have gone otherwise.) Total OECD inventory from August 1985 through February 1986 was being built up slightly, by about 7 percent, the reverse of normal seasonal drawdown patterns. Such behavior would tend to slow the rate of price decrease, rather than accelerate it. However, one factor complicating the analysis was the adoption of "netback" pricing by many OPEC countries in the last quarter of 1985 . Under this scheme the price of crude oil was determined by the prices at which the products were sold, plus some guaranteed markup for the refiners. The shift to this type of pricing scheme would have had a positive effect upon inventories of both crude oil and refined products. Thus the inventory buildup by itself provides inconclusive evidence on the question of destabilizing inventory behavior. 
and their Arab neighbors on the Persian Gulf have a greater long-term stake in the world oil market than do most other OPEC members and most non-OPEC producers, who will have relatively little oil left in twenty years. The Saudis do not want the long-term health of their market jeopardized by irreversible fuel-switching or the development of alternative energy sources.

Some simulation runs from my OPEC Pricing Simulation Model will shed light upon the 1986 oil price collapse and highlight the choices facing OPEC for the future. ${ }^{26}$ The projections that follow are illustrative and are not to be interpreted as forecasts. Although I believe that the underlying parameter values assumed are quite reasonable, I am aware of the unavoidable uncertainty involved..$^{27}$

The model is an annual model of the world market for crude oil. In it, price, measured in 1985 dollars, is determined by OPEC, which produces the difference between world oil demand and non-OPEC supply. ${ }^{28}$ The model is disaggregated regionally into non-OPEC and a country-bycountry disaggregation of OPEC.

The thirteen members of OPEC are divided into three groups. The "Core" of OPEC consists of Saudi Arabia and its immediate neighbors, Kuwait, the United Arab Emirates, and Qatar. Iran and Iraq are grouped together because their output has been reduced by war and will increase when the conflict is resolved; their output levels are assumed to be exogenous to the model. ${ }^{29}$ The rest of OPEC consists of Algeria, Ecuador, Gabon, Indonesia, Libya, Nigeria, and Venezuela. They are assumed to produce at the same level in 1986 as they did in $1985 .{ }^{30}$ For 1987 and

26. The model is described in Dermot Gately, "OPEC: Retrospective and Prospects, 1973-1990," European Economic Review, vol. 21 (May 1983), pp. 313-31; and in Gately, Kyle, and Fischer, "Strategies for OPEC's Pricing Decisions." It was a participating model in the EMF world oil study and is commercially available on the IBM PC.

27. See the discussion above of the work by Hogan and Leiby. See also Gately, Kyle, and Fischer, "Strategies for OPEC's Pricing Decisions."

28. World oil demand is calculated as a constant-elasticity function of current and past prices (with a uniform lag for the effects of past prices). I assume that world GNP grows at 2.5 percent annually, regardless of the level of oil prices. Non-OPEC supply is calculated from a competitive (linear) supply function.

29. Their output is assumed to be 4 million bpd in 1985 and 1986, rising gradually to 6 million bpd by 1988 , and kept constant at that level thereafter. The remainder of OPEC is assumed to "make room" for the extra 2 million bpd output from Iran and Iraq in 1986-88.

30. Although there is some variation within this group, on balance this is a reasonable description of what has occurred. 
beyond, they share equally with the Core any increases in the demand for OPEC oil (above that produced by Iran and Iraq); they also share decreases with the Core, but not equally: the Core bears 70 percent of further cutbacks needed.

Six cases are simulated: three different initial prices- $\$ 26, \$ 18, \$ 10-$ for each of two OPEC output ceilings-25 million bpd and 35 million bpd. Price starts at one of three initial prices in 1986 and remains at that level until the demand for OPEC oil reaches the assumed output ceiling, after which time the market-clearing price is calculated. The $\$ 26$ initial price is intended as a reference case and can be thought of as the 1985 status quo. With the other two, the 1986 price drops to either $\$ 18$ or $\$ 10$ because of output increases by OPEC's Core. The path to a 25 million bpd output ceiling can be thought of as a stylized "return to normality" for OPEC. ${ }^{31}$ The 35 million bpd level is an alternative ceiling, suggested by some who believe it to be preferable for the Core, from whom the additional 10 million bpd output is assumed to come.

Four of these six cases are graphed in figure 8 , which shows the price path of oil starting from each of the three initial prices with a 25 million bpd ceiling and starting from $\$ 10$ with a 35 million bpd ceiling. (The two cases that are not graphed could be interpolated.) The corresponding levels of Core output and resulting demands for OPEC oil and for world oil are shown in figure 9. The implications of these price paths for the Core's revenue are depicted in figure 10. The net present value of 19862000 revenue and of oil reserves remaining in the year 2000, for all six cases, are summarized in figures 11 and 12 , using discount rates of 10 percent and 20 percent, respectively.

As figures 8 and 9 show, the lower price drops in 1986, the more rapidly demand for OPEC oil increases, both because world oil demand increases more rapidly and because non-OPEC supply is deterred. If price stays at $\$ 26$, OPEC does not reach 25 million bpd until 1997. But if price drops to $\$ 18$, OPEC reaches 25 million bpd in 1994 . With price at \$10, OPEC reaches 25 million bpd in 1990 and 35 million bpd in 1995.

The $\$ 26$ constant-price case requires OPEC's Core to continue restricting its output well into the mid-1990s. Only then does the demand for OPEC oil get back above 20 million bpd. But if the Core increases its

31. At the 25 million bpd level, OPEC's Core produces at 66 percent of its 1985 capacity, the rest of OPEC at 85 percent of its 1985 capacity, and Iran and Iraq at 6 million bpd total. 
Figure 8. Alternative Price Paths, 1985-2000 ${ }^{\mathrm{a}}$

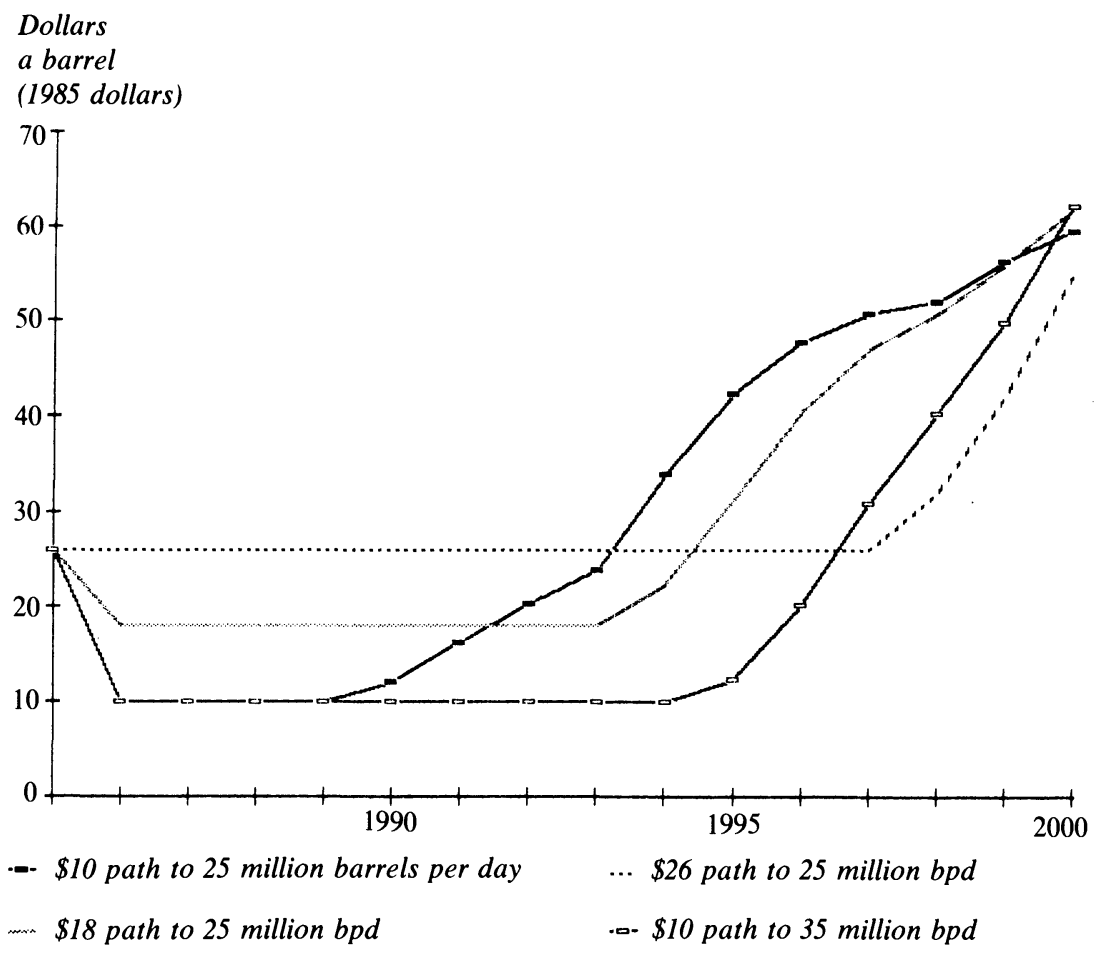

Sources: Author's calculations using an OPEC pricing simulation model. For a description of the model, see text and Dermot Gately, "OPEC: Retrospective and Prospects, 1973-1990," European Economic Review, vol. 21 (May 1983), pp. 313-31; and Gately and John F. Kyle with Dietrich Fischer, "Strategies for OPEC's Pricing Decisions," European Economic Review, vol. 10 (February 1977), pp. 209-30.

a. In the four simulations price is determined by OPEC at one of the three initial prices in 1986 and remains at that level until the demand for OPEC oil reaches the assumed output ceiling ( 25 million bpd or 35 million bpd), after which the market-clearing price is calculated.

1986 output to about 8 million bpd, so that price falls to $\$ 18$, it can maintain that 8 million bpd output level until the early 1990s. Thereafter, it can gradually increase its output as the demand for OPEC oil increases, up to the 25 million bpd target. Going still further, if the Core increases its output to about 11 million bpd, which is still only two-thirds of its 1985 capacity level, the 1986 price falls to $\$ 10$. In that case it could maintain that output level and the $\$ 10$ price until 1990, while the growth in demand for OPEC oil to 25 million bpd is met by Iran, Iraq, and the rest of OPEC. With a 35 million bpd ceiling, the $\$ 10$ price continues until 1995, as the Core increases its output by 10 million bpd between 1989 and 1995. 
Figure 9. World and OPEC Oil Demand and Output by OPEC Core, 1985-2000a

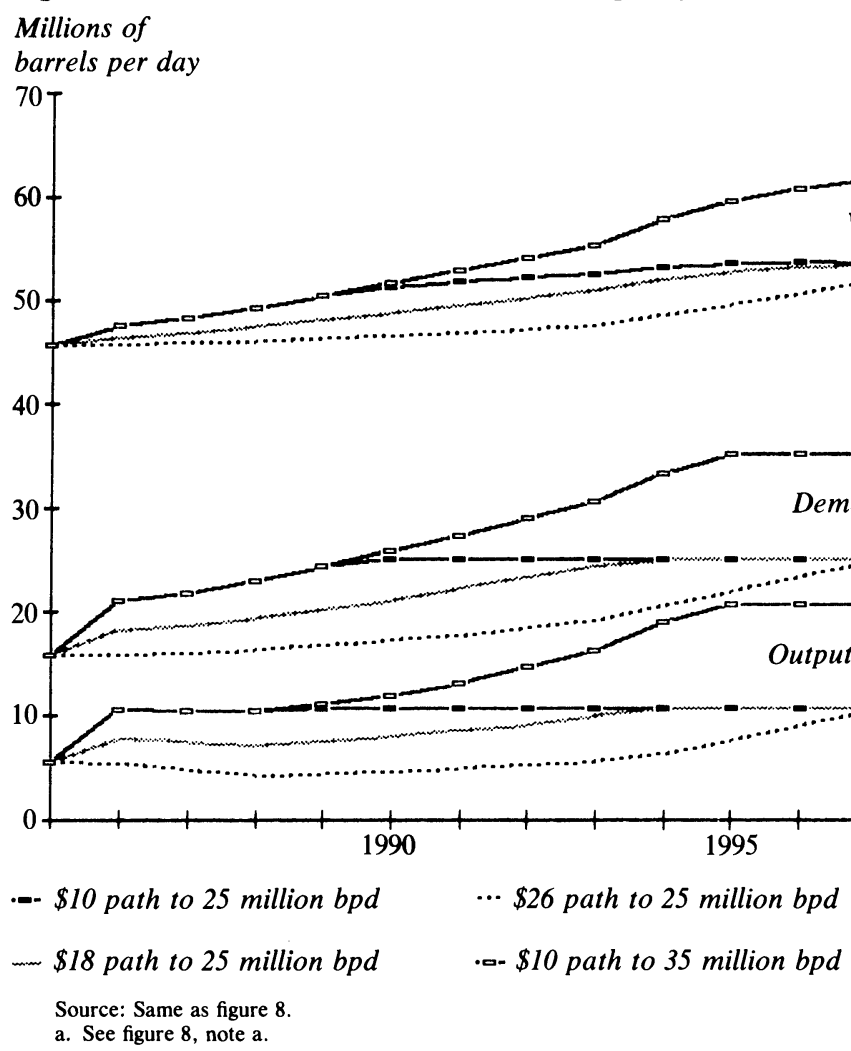

The revenue implications of these cases help us understand what happened in 1986. As figure 10 shows, the Core's 1986 revenue is not much affected whether price is $\$ 26$ or $\$ 18$. But if price falls to $\$ 10$ the Core's 1986 revenue falls significantly, by almost 20 percent. In the short run, therefore, the Core faces a demand curve for its oil with a price elasticity about equal to unity, at least down to a price of $\$ 18$ : output increases are offset almost exactly by price declines, so that revenue is constant. But for a further price decline to $\$ 10$, it faces an inelastic shortrun demand curve: price falls and revenue decreases. Over the entire range from $\$ 26$ down to $\$ 10$, however, the short-run demand curve is inelastic for the rest of OPEC and for OPEC as a whole: the lower the price, the lower is their 1986 revenue.

As figure 10 shows, the constant $\$ 26$ price yields the Core lower 
Figure 10. Annual Revenue for OPEC Core, 1985-2000

Billions of 1985 dollars

(logarithmic scale)

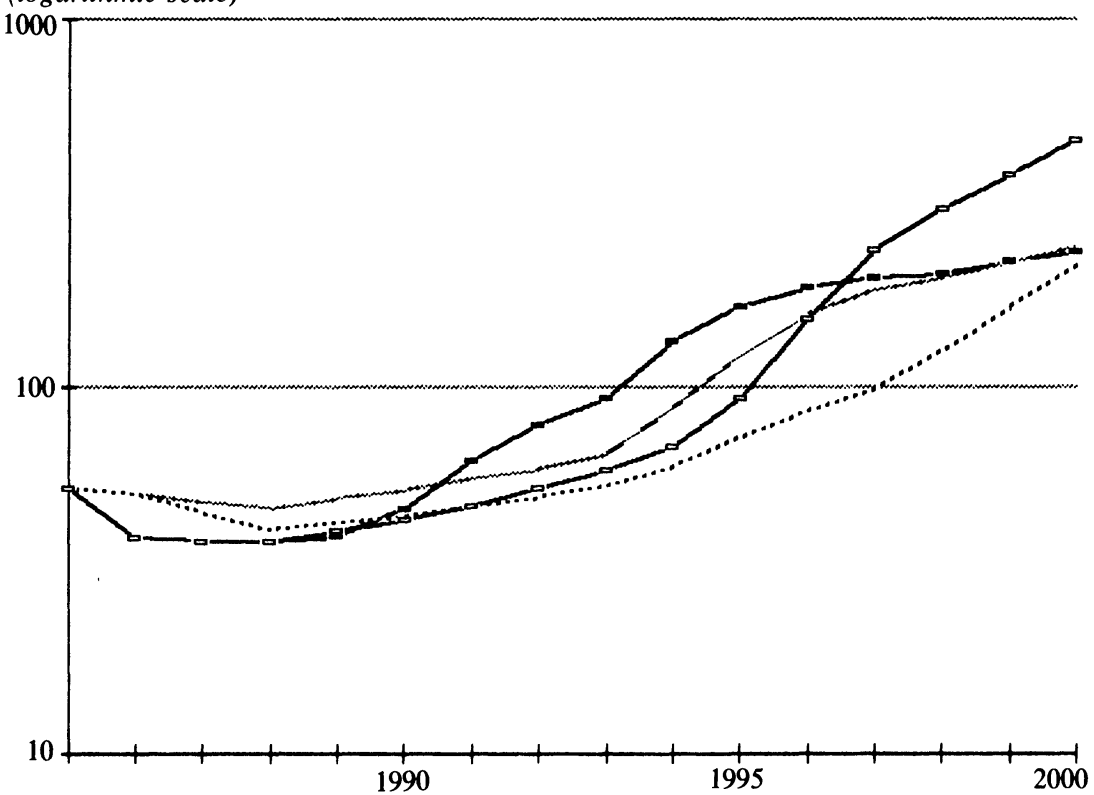

-.-\$10 path to 25 million bpd

... \$26 path to 25 million bpd

- \$18 path to 25 million bpd

- $\$ 10$ path to 35 million bpd

Source: Same as figure 8.

a. See figure 8 , note a.

revenue from 1987 through the early 1990s than the $\$ 18$ price, because the high price requires continued restriction of output. The $\$ 18$ initial price yields the best revenue results, since the Core's revenue stays virtually constant. The $\$ 10$ initial price has the lowest revenue of all for the first two years; it remains constant for the late 1980s, increasing only when OPEC reaches 25 million bpd (or 35 million bpd) and the price rises substantially, to market-clearing levels.

Beyond the early 1990s the revenue results are dominated by the price effects of demand for OPEC oil reaching 25 million bpd, after which a market-clearing price is calculated. In these simulations, the lower the price, the sooner demand for OPEC oil gets back to 25 million bpd, and the sooner price and revenue increase.

The net present values (NPV) for pre-2000 OPEC revenue and post- 
Figure 11. Net Present Value, OPEC, Discount Rate 10 Percent $^{\mathrm{a}}$

Billions of

1985 dollars

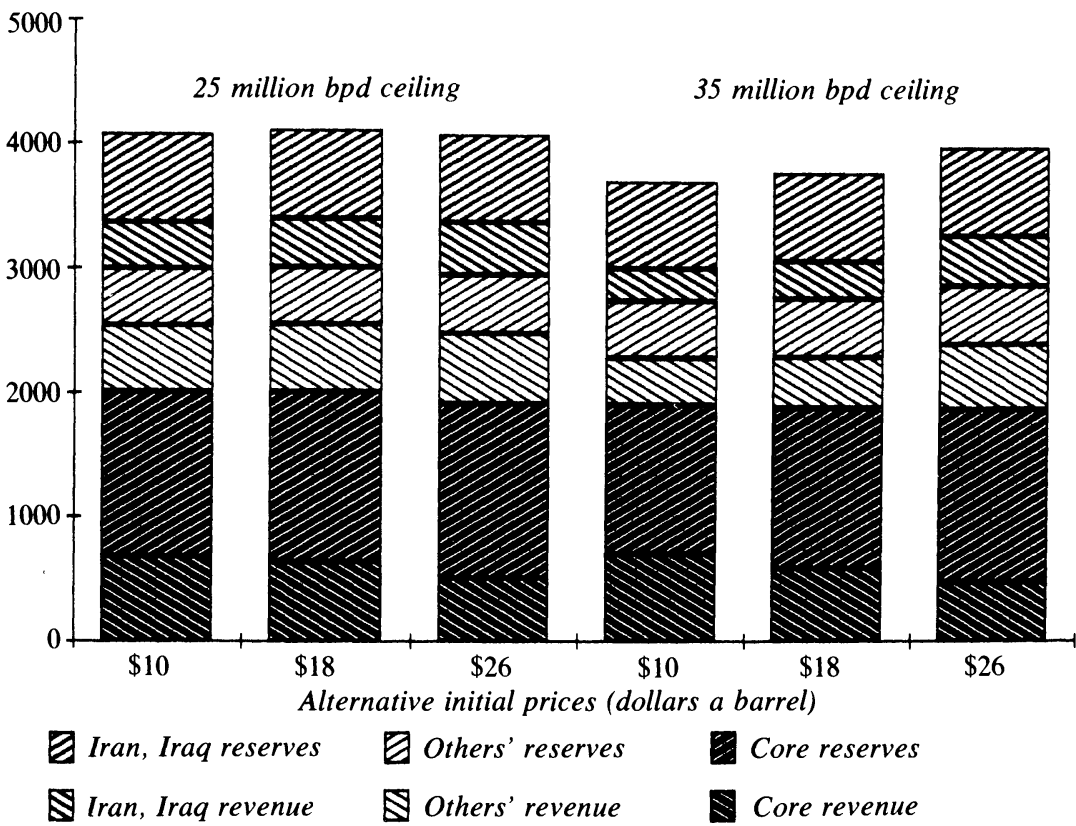

Source: Same as figure 8.

a. Net present value from 1986-2000 revenue and post-2000 oil reserves. In the model it is assumed that post2000 oil reserves would be sold at a price of $\$ 60$ a barrel and that 5 percent of reserves would be produced each year. Thus a billion barrels of post- 2000 oil would be worth $\$ 4.35$ billion today. If one assumes a lower post-2000 price, then the valuation of post-2000 reserves would be proportionally reduced.

2000 reserve valuation are shown in figure 11 for each of the six cases, using a discount rate of 10 percent. ${ }^{32}$ With a 25 million bpd ceiling, the OPEC totals are about the same for the three initial prices. But a 35 million bpd ceiling yields smaller totals, especially in the lower-priced cases, because it means less pre-2000 revenue for non-Core members. For the Core alone, the six cases yield about the same total NPV: the smaller pre-2000 revenue for the $\$ 26$ path is offset by the value of the larger post-2000 reserves.

32. I assume that post-2000 oil reserves would be sold at a price of $\$ 60$ and that 5 percent of reserves would be produced each year. Thus, a billion barrels of post-2000 oil would be worth $\$ 4.35$ billion today. If one assumes a lower post-2000 price, then the valuation of post-2000 reserves would be proportionately reduced. 
Figure 12. Net Present Value, OPEC, Discount Rate 20 Percent $^{\mathrm{a}}$

Billions of

1985 dollars

$1400 \mathrm{~T}$

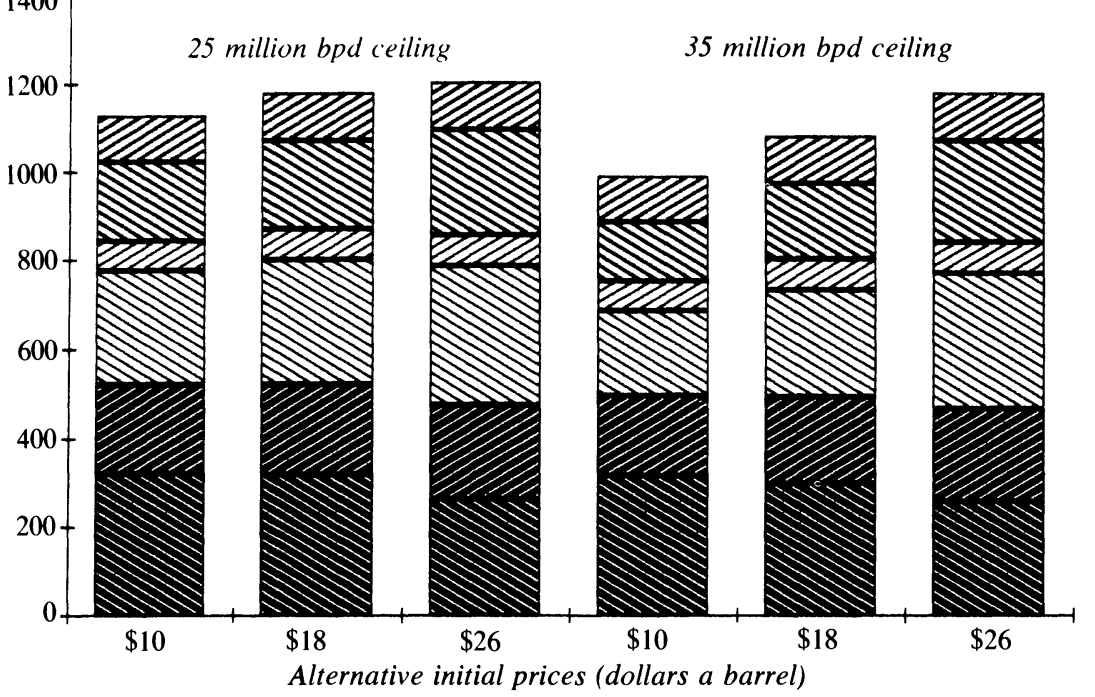

\section{Iran, Iraq reserves \\ $\square$ Others' reserves \\ Core reserves \\ $\mathbf{\$}$ Iran, Iraq revenue \\ Others' revenue \\ 要 Core revenue}

Source: Same as figure 8

a. See figure 11 , note a.

If a 20 percent discount rate is used instead, the results (figure 12) are slightly different. ${ }^{33}$ The totals are smaller, of course, with a higher discount rate, and the value of post-2000 oil reserves is a much smaller fraction of the totals. Another difference is that the rest of OPEC would be substantially better off the higher the price and the lower the output ceiling. But for the Core, much is the same as when a 10 percent discount rate is used. The NPV "flatness" across cases remains the same, as does the preference for $\$ 10$ or $\$ 18$ if only 1986-2000 revenue is considered.

To sum up, the results of these simulations help clarify what has

33. See M. A. Adelman, “Oil Producing Countries' Discount Rates" (MIT Energy Lab Working Paper, July 1986). Adelman argues that a subjective discount rate of 20 percent, or more, is appropriate because many OPEC governments have short time horizons, face the risk of political instability, and behave like highly leveraged, undiversified corporations with precommitments to spend much if not all of their income. 
happened in 1986 and what might be expected in the future. For the Core, the 1986 price declines have been offset by output increases so that 1986 revenue has not been substantially affected. But there is a limit to the Core's ability to offset price declines by increasing output. The July 1986 price of $\$ 12$ is too low even for the Core's best short-run interest: its 1986 revenue would increase if it restricted output unilaterally and let price increase to the \$16-\$20 level. The fact that OPEC's agreement in early August 1986 at Geneva requires virtually all OPEC members to cut back makes such output restriction even better for the Core.

Over the longer run, the Core would prefer an initial price lower than the 1985 status quo of $\$ 26$, which would require them to restrict output for ten more years, with revenue declines for the next few years. But they would have no strong preference for any of the other cases simulated. The rest of OPEC, however, would clearly prefer the lower output ceiling and a higher initial price, especially if they use a higher discount rate.

\section{What Should We Have Expected for 1985-86?}

Now that it has happened, it is possible to understand the 1986 price collapse. But it certainly came as a surprise to most observers at the time. ${ }^{34}$ Analysts in 1985 were expecting continuing weakness in price but not a collapse. It seemed unlikely in 1985 that Saudi Arabia would break with the rest of OPEC and take the high-profile, politically risky strategy of forcing a price collapse. ${ }^{35}$ The risks were not only political

34. A few analysts may not have been so surprised. See George Daly, James M. Griffin, and Henry B. Steele, "The Future of OPEC: Price Level and Cartel Stability,"' Energy Journal, vol. 4 (January 1983), pp. 65-77; Eliyahu Kanovsky, "An Economic Analysis of Middle East Oil"' in Middle East Contemporary Survey (Holmes and Meier, 1981); S. Fred Singer, "The Price of World Oil," Annual Review of Energy, vol. 8 (1983), pp. 451-508; Arlon R. Tussing, “'Oil Prices Are Still Too High,” Energy Journal, vol. 6 (January 1985), pp. 9-12.

35. For a detailed description of Saudi cautiousness, see Theodore Moran, "Modeling OPEC Behavior: Economic and Political Alternatives," in Griffin and Teece, OPEC Behavior and World Oil Prices, pp. 94-130. 
and economic. There were also external military risks: a hostile Iran might strike from across the Persian Gulf, widening its war with Iraq. Or, joining with Libya, Iran might foment destabilizing activity within Saudi Arabia.

But if the price collapse seemed unlikely from the vantage point of 1985 , from the perspective of 1980 it can only be described as astounding. While many observers in 1980 expected some softness in oil prices after the 1979-80 price increases, few expected declining prices to erode the entire doubling by 1985 , and fewer still expected the 1986 price collapse. The biggest surprise was the continuing increase in non-OPEC production (15 percent greater in 1985 than in 1980), especially from a large number of relatively small producers. The exploration and development underlying these increases had been spurred by the price increases of the 1970s and had picked up sufficient momentum and incurred sufficient fixed costs not to be deterred by the price declines of the early $1980 \mathrm{~s}$.

For OPEC most of the damage occurred during 1980-82, when demand for OPEC oil fell from 30 million bpd to below 20 million bpd. Part of the decline was the result of increasing non-OPEC supply. But most was the result of a roughly 10 percent decline in world oil demand between 1979 and 1982 due to falling economic growth rates in the 1980-82 recession, the lagged response to the 1973-74 and 1979-80 price increases, and the decontrol of U.S. oil prices, which raised prices significantly during 1979-81. ${ }^{36}$

The 1980-82 decline in demand for OPEC oil came as something of a surprise. Should the 1983-85 sluggish market have surprised us? The continuing increase in non-OPEC supply, even in the face of price declines, was unexpected. But the sluggish growth in world oil demand itself should not have been very surprising. In fact, oil demand forecasts as of 1982 could have forecast the 1983-85 sluggishness in world oil demand fairly accurately. The weakness of the oil market, despite the declining dollar-denominated price of oil, was the result of the lagged

36. Although the late-1970s time series estimates for individual countries' demand responsiveness to price were relatively low, international cross-section studies yielded higher response estimates, which turned out to be supported by the demand declines of 1979-82. See Robert S. Pindyck, The Structure of World Energy Demand (MIT Press, 1979); and James M. Griffin, Energy Conservation in the OECD: 1980 to 2000 (Ballinger, 1979). 
adjustment to the 1979-80 price increases, combined with economic growth rates in 1983-85 only 60 percent of those in 1976-79 and less than half those in 1960-73. ${ }^{37}$

To illustrate how accurately 1982 demand forecasts could have projected 1983-85 market conditions, I used 1950-82 data to estimate, for each of the six largest countries in the OECD, a constant-elasticity (log-linear) equation for oil demand as a function of that country's GDP, own-currency price of crude oil, and the effects of lagged prices. ${ }^{38}$ In all cases but Japan and the United States, I used a Koyck lag for the effects of past prices; that is, I used the previous year's oil demand level as an explanatory variable:

$$
\begin{aligned}
\log \left(\text { Demand }_{t}\right)= & c+\alpha * \log \left(\text { Income }_{t}\right)+\beta^{*} \log \left(\text { Price }_{t}\right) \\
& +k^{*} \log \left(\text { Demand }_{t-1}\right)
\end{aligned}
$$

For Japan and the United States, I assumed that the lagged-price coefficients took the form of a cubic polynomial-distributed lag, with a ten-year lag length: ${ }^{39}$

$$
\log \left(\text { Demand }_{t}\right)=c+\alpha^{*} \log \left(\text { Income }_{t}\right)+\sum \beta_{i} \log \left(\text { Price }_{t-1}\right),
$$

where the $\beta_{i}$ coefficients were of the form (with no end-point restrictions):

$$
\beta_{i}=\delta_{0}+\delta_{1} i+\delta_{2} i^{2}+\delta_{3} i^{3} .
$$

The estimated coefficients for these equations with 1950-82 data are presented in table 1 for each of the six countries. ${ }^{40}$ With these equations I calculated demand forecasts for 1983-85, using two alternative sets of assumptions about gross domestic product and the own-currency price

37. The increased foreign exchange value of the dollar does not explain much of the 1983-85 oil demand sluggishness, because it was offset by declining dollar-denominated oil prices. In none of the six largest OECD countries was the own-currency price of oil higher in 1985 than in 1982 (figure A-1).

38. I used the real U.S. price of imported crude oil, converted to that country's currency, using that year's exchange rate.

39. For the United States, I used a cubic polynomial-distributed lag because it had superior results; see Dermot Gately and Peter Rappoport, "The Adjustment of US Oil Demand to the Price Increases of the 1970's: Have the Conservation Gains Been Overstated?' (New York University, April 1986). The price variable was the refiners' acquisition cost of crude oil, not the cost of imported crude oil. In the case of Japan, a Koyck-lag specification yielded the wrong signs for price and income, so I also used a cubic polynomial-distributed lag.

40. Estimating the same equations using three additional years' data (1983-85) does not change the results significantly. 
Table 1. OECD Oil Demand Equations, France, Germany, Italy, United Kingdom, Japan, and the United States, 1950-82

\begin{tabular}{|c|c|c|c|c|c|c|}
\hline $\begin{array}{c}\text { Independent } \\
\text { variable and } \\
\text { summary statistic }\end{array}$ & France & Germany & Italy & $\begin{array}{c}\text { United } \\
\text { Kingdom }\end{array}$ & $J_{a p a n^{\mathrm{b}}}$ & $\begin{array}{l}\text { United } \\
\text { States }\end{array}$ \\
\hline Constant & $\begin{array}{c}-3.43 \\
(-2.21)\end{array}$ & $\begin{array}{l}-1.83 \\
(-0.76)\end{array}$ & $\begin{array}{c}-6.14 \\
(-3.32)\end{array}$ & $\begin{array}{l}-3.83 \\
(-2.30)\end{array}$ & $\begin{array}{l}2.76 \\
(1.07)\end{array}$ & $\begin{array}{c}-2.97 \\
(-4.61)\end{array}$ \\
\hline Income & $\begin{array}{c}0.57 \\
(2.54)\end{array}$ & $\begin{array}{c}0.39 \\
(1.03)\end{array}$ & $\begin{array}{l}1.53 \\
(3.70)\end{array}$ & $\begin{array}{c}0.81 \\
(2.38)\end{array}$ & $\begin{array}{c}1.43 \\
(18.00)\end{array}$ & $\begin{array}{c}0.88 \\
(10.88)\end{array}$ \\
\hline Price & $\begin{array}{l}-0.18 \\
(-5.36)\end{array}$ & $\begin{array}{l}-0.20 \\
(-2.47)\end{array}$ & $\begin{array}{l}-0.22 \\
(-4.75)\end{array}$ & $\begin{array}{l}-0.15 \\
(-3.59)\end{array}$ & $\begin{array}{l}-0.07 \\
(-2.63)\end{array}$ & $\begin{array}{l}-0.05 \\
(-2.45)\end{array}$ \\
\hline Demand, lagged & $\begin{array}{l}0.75 \\
(6.85)\end{array}$ & $\begin{array}{c}0.80 \\
(6.23)\end{array}$ & $\begin{array}{l}0.36 \\
(2.18)\end{array}$ & $\begin{array}{c}0.72 \\
(6.24)\end{array}$ & $\ldots$ & $\ldots$ \\
\hline $\begin{array}{l}\text { First-order autore- } \\
\text { gressive term }\end{array}$ & $\begin{array}{c}-0.09 \\
(-0.42)\end{array}$ & $\begin{array}{c}0.20 \\
(0.94)\end{array}$ & $\begin{array}{c}0.05 \\
(0.20)\end{array}$ & $\begin{array}{l}0.15 \\
(0.67)\end{array}$ & $\begin{array}{c}0.19 \\
(0.87)\end{array}$ & $\begin{array}{c}1.09 \\
(-5.82)\end{array}$ \\
\hline $\begin{array}{l}\text { Second-order auto- } \\
\text { regressive term }\end{array}$ & $\begin{array}{c}0.10 \\
(0.55)\end{array}$ & $\begin{array}{c}0.04 \\
(0.21)\end{array}$ & $\begin{array}{c}0.00 \\
(0.01)\end{array}$ & $\begin{array}{c}0.08 \\
(0.34)\end{array}$ & $\begin{array}{c}0.10 \\
(0.66)\end{array}$ & $\begin{array}{c}-0.32 \\
(-1.96)\end{array}$ \\
\hline $\begin{array}{l}\text { Summary statistic } \\
\bar{R}^{2}\end{array}$ & 0.994 & 0.991 & 0.993 & 0.984 & 0.993 & 0.996 \\
\hline $\begin{array}{l}\text { Standard error of } \\
\text { regression } \\
\text { Durbin-Watson }\end{array}$ & 0.050 & 0.094 & 0.065 & 0.055 & 0.045 & 0.017 \\
\hline $\begin{array}{c}\text { statistic } \\
\text { One-year price }\end{array}$ & 2.09 & 2.06 & 1.94 & 1.75 & 2.42 & 2.42 \\
\hline $\begin{array}{l}\text { elasticity } \\
\text { Long-run price } \\
\text { elasticity }\end{array}$ & -0.18 & -0.20 & $\begin{array}{l}-0.22 \\
-0.34\end{array}$ & $\begin{array}{l}-0.15 \\
-0.54\end{array}$ & $\begin{array}{l}-0.07 \\
-1.09\end{array}$ & $\begin{array}{l}-0.05 \\
-0.37\end{array}$ \\
\hline
\end{tabular}

Source: Author's estimates. See equations 1, 2, and 3 in text.

a. Dependent variable is total oil demand in each country. The price measures are the real U.S. price of imported crude oil, converted to that country's currency, using the exchange rate for the corresponding year. In all cases but Japan and the United States the previous year's demand is used as an explanatory variable. Numbers in parentheses are $t$-statistics.

b. For Japan and the United States, the lagged price coefficients took the form of a cubic polynomial-distributed lag of ten years. For other countries, a Koyck lag was used. The cubic polynomial-distributed lag specification complicates any comparisons of the coefficients, but the calculated elasticities are comparable.

of crude oil: that the actual values for 1983-85 GDP and own-currency price had been known as of 1982 and that the 1983-85 own-currency price would be constant and the 1983-85 GDP growth rates would be the same as those experienced in the 1976-79 period of moderately high growth. ${ }^{41}$ The summary results for all six countries are graphed in figure

41. These price assumptions are reasonably accurate for France, Italy, and the United Kingdom, but overstate the price for Japan and Germany and especially the United States. The GDP growth assumptions overstate growth by 40 percent for all but the United Kingdom and United States. 
Figure 13. Oil Demand in Six OECD Countries, 1962-85; Fitted Values, 1962-82; and Forecasts, 1983-85

Millions of

barrels per day

Forecast,

35

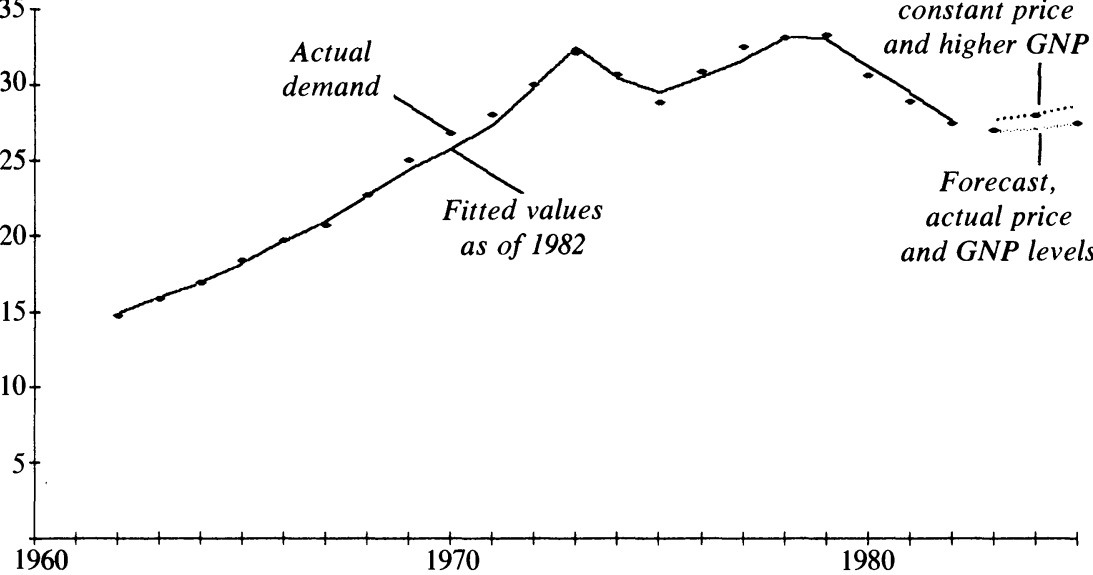

Source: DOE, Annual Energy Review 1985 , p. 239 , and authors' calculations. See text description.

a. The six OECD countries are France, Germany, Italy, Japan, the United Kingdom, and the United States.

13. (More detailed results for individual countries are presented and discussed in the appendix.) With the actual values for 1983-85 owncurrency price and GDP growth rates, the demand equations would have forecast the 1985 demand level quite accurately. Slight overestimates for Germany, Italy, and the United Kingdom would have been offset by an underestimate for Japan. But with the assumption of constant owncurrency price and higher (1976-79) economic growth rates, 1985 oil demand would have been overestimated by about 1 million bpd, or about 3 percent of these countries' demand. The overestimate would have been the result of lower-than-expected economic growth. ${ }^{42}$

Thus the sluggish oil market in 1983-85 should not have been much of a surprise, although it may have surprised some OPEC producers hoping for an oil demand recovery similar to that of 1975-78. Perhaps with higher eonomic growth, world oil demand could have been expected to be at most 1 or 2 million bpd higher by 1985 , and non-OPEC supply might have been expected to be 2 million bpd lower. This 3 or 4 million

42. If the actual price decline had been expected in 1982 , then the overestimate would have been greater. 
bpd shortfall in demand for OPEC oil was enough to make the difference, causing Saudi Arabian production to fall below 3 million bpd in the summer of 1985, precipitating their output increases and the 1986 price collapse.

From this I conclude that whenever the Saudis and their allies are "near the edge," with very low capacity utilization, additional setbacks could result in a repetition of the sharp price declines experienced in 1986. A serious recession in 1987 or sharp increases in ouput from Iran and Iraq could return OPEC to its 1985 position, with the same internal conflict and risk of price declines.

\section{The Outlook}

The July 1986 crude oil price of $\$ 12$ a barrel was clearly an overcorrection of the 1973-74 and 1979-80 price increases and could not be sustained long. With oil at that price, Saudi Arabia and its allies would suffer revenue losses, even at the increased production levels that precipitated the price collapse. The Saudis thus had every incentive to cut their own output, even unilaterally. The fact that they could get the rest of OPEC to agree to cut back too made a price increase that much more inevitable.

Although OPEC will continue to have difficulty in getting its members to honor their output quotas, it ought to be easier than it was in the past. With the 1986 price collapse so fresh in mind, Saudi threats to increase output once again will have to be taken seriously. As Samuel Johnson observed about the prospect of being hanged in a fortnight, the idea of $\$ 8$ oil concentrates the mind wonderfully. This 1986 price collapse and its "lessons" for the rest of OPEC could well provide the same type of folk memory within OPEC as did the 1930 experience of 10-cent oil in East Texas for American oilmen.

But it is not just OPEC's painful memory of 1986 that guarantees that oil prices will go up. There have been no changes in the world oil market fundamental enough to sustain an oil price of $\$ 12$ a barrel. Although nonOPEC oil production has increased by more than 50 percent since 1973, it appears to be within 10 percent of its peak level. The world's proved oil reserves have not increased substantially, despite an enormous amount of exploration, and OPEC's share of world oil reserves has not 
changed. Despite a great deal of research and development, there is still no alternative energy source that is cheap, clean, and plentiful. Perhaps the most encouraging alternative would be natural gas. Oil's share of world energy use has declined, especially since 1978, but it is still the world's most important fuel, comprising 40 percent of the total fuel used. Prices of other fuels increased greatly between 1973 and 1981 and have not declined nearly as much as oil in the past five years. Oil demand has grown in the centrally planned economies and developing countries, even though it has declined in the United States and in the rest of the OECD. The demand-reducing adjustment to the 1973-74 and 1979-80 price increases has been decelerating and perhaps will be entirely reversed by the 1983-86 price reductions. World income growth will continue to increase the demand for oil and other forms of energy.

Figure 14 projects oil demand growth in the United States from 1985 to 2000. The equations underlying the projections are based on econometric work using data through $1985 .{ }^{43}$ Both projections assume 3 percent annual economic growth and price held constant at its 1985 level. ${ }^{44}$ In the "low-demand specification" a twenty-year period for adjustment to past price increases is assumed; the estimated income elasticity is 0.77 . In the "high-demand specification" a ten-year adjustment period is assumed; the estimated income elasticity is 1.0. The two specifications have basically the same lagged-price coefficients for the first ten years. The conclusion to be drawn is moderately sobering: unless one assumes that the period of lagged adjustment is much longer than ten years and that there is still to come a significant lagged response to the 1973-74 and 1979-80 price increases, there is not much time series evidence for the optimistic view that demand is highly responsive to price.

How soon can we expect price to return to the level of 1985 or 1980 ? Briefly, when market conditions and OPEC capacity utilization warrant. Price could return to its 1985 level within one to five years, to its 1980 level within five to ten years, perhaps longer. Once non-OPEC supply has clearly peaked, price can be expected to increase much more rapidly. And with a major disruption, price could rise to those levels within weeks. With oil prices, there is unavoidable uncertainty, the range of

43. See Gately and Rappoport, "The Adjustment of US Oil Demand."

44. Taking account of the 1986 price decline would, of course, make demand grow even more rapidly. 
Figure 14. Oil Demand, 1970-85, and Demand Projections to 2000, United States ${ }^{\mathrm{a}}$

Millions of

barrels per day

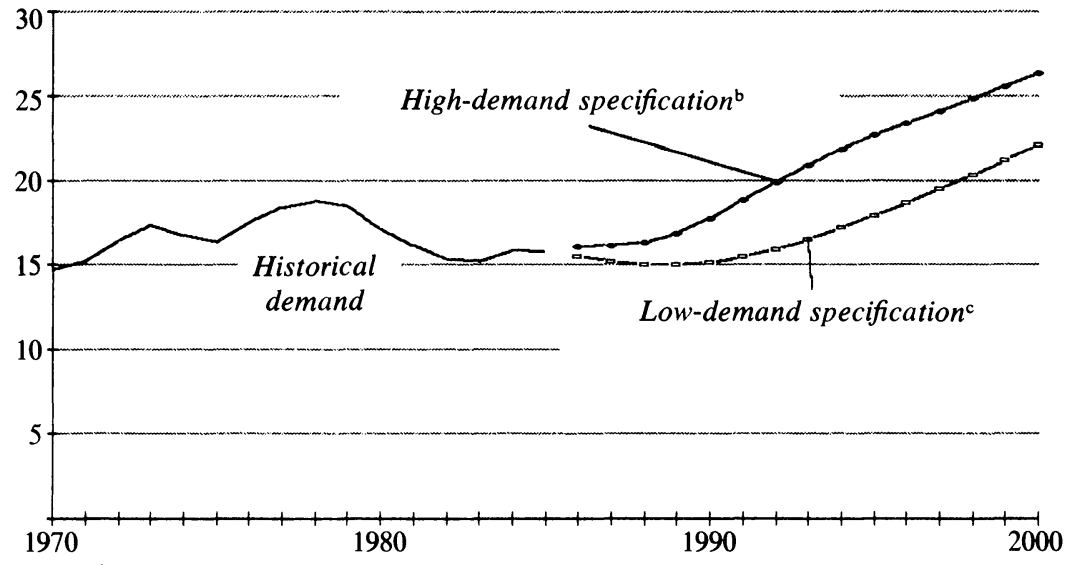

Source: Dermot Gately and Peter Rappoport, "The Adjustment of U.S. Oil Demand to the Price Increases of the 1970's: Have the Conservation Gains Been Overstated?" (New York University, April 1986).

a. GNP is assumed to grow at an annual rate of 3 percent, and prices are assumed constant at 1985 level.

b. Ten-year adjustment to price increases and 1.0 income elasticity.

c. Twenty-year adjustment to price increases and 0.77 income elasticity.

which is well captured in figure 7 above, with a little stretching of the price distributions downward.

Assuming that the demand for OPEC oil increases to 22-24 million bpd within the next few years, how will OPEC respond? In the 1990s, will it continue increasing output above $25-27$ bpd, or will it keep its output below that level and let price rise? I believe it will let output expand up to about 30 million bpd, which will be a practical upper limit for OPEC. Although OPEC has the oil reserves to support a much higher level of output, perhaps as high as $45-50$ million bpd, it would probably not be willing to exhaust its reserves that rapidly. Nor, probably, would the OECD countries, if blessed with some farsighted political leadership, be willing to become as dependent upon OPEC as they were in the 1970s. As Hall and Pindyck have observed, the industrialized world can have low prices or energy independence, but not both. ${ }^{45}$

Apart from a disruption, when price rises it will probably do so gradually. Having witnessed the dangers of major, abrupt price increases

45. Robert E. Hall and Robert S. Pindyck, "The Conflicting Goals of National Energy Policy," The Public Interest, vol. 47 (Spring 1977), pp. 3-15. 
since 1979-80, Saudi Arabia and the rest of OPEC can be expected to be much more cautious about raising price abruptly, to the degree that they do so intentionally rather than accidentally. Such price fluctuations are in nobody's interest: predictability and smoother price changes are preferable to uncertainty and abrupt changes. ${ }^{46}$ As I wrote in 1977, in an article about OPEC pricing strategies:

One rule of thumb [target-capacity-utilization] pricing strategy that is likely to serve OPEC very well for the foreseeable future . . . is a strategy that is relatively cautious about further major, abrupt price increases. Such a strategy would increase price only gradually when market conditions warrant and would cut price aggressively if necessary to defend OPEC's market position. ${ }^{47}$

Abrupt price increases are, however, possible as soon as demand for OPEC oil recovers substantially enough to reach a level near production capacity. And unfortunately the West will be only slightly less vulnerable to such a disruption than it was in 1979-80. Since 1973 there has been little improvement in short-run price-responsiveness, apart from increased fuel-switching capability in electricity generation. Moreover, despite a significant increase in the U.S. Strategic Petroleum Reserve under the Reagan administration, the reserve is still only about half as large as originally planned for 1980 , despite ample opportunity to purchase oil in a slack market.

APPENDIX

\section{Oil Demand Forecasts for Six OECD Countries}

THIS APPENDIX details the 1982 forecasts of $1983-85$ oil demand for the United States, France, Germany, Italy, the United Kingdom, and Japan that were presented in aggregate form in figure 13.

46. Of course, if the world's reduced dependence on OPEC is easily reversible by a period of lowered prices, then a policy which "cycles" on price could serve OPEC quite well. OPEC could raise price abruptly to take advantage of short-term inelasticities, then cut price sharply when the lagged response of world oil demand and non-OPEC supply threatened their market. This cycle could be repeated to OPEC's benefit (intentionally or not) as long as the world had a short memory.

47. Gately, Kyle, and Fischer, "Strategies for OPEC's Pricing Decisions,"' p. 211. 
Figure A-1. Own-Currency Price of Imported Crude Oil, Italy, United Kingdom, France, United States, Germany, and Japan, 1970-85

Price index,

$1970=100$

$1200 \mathrm{~T}$

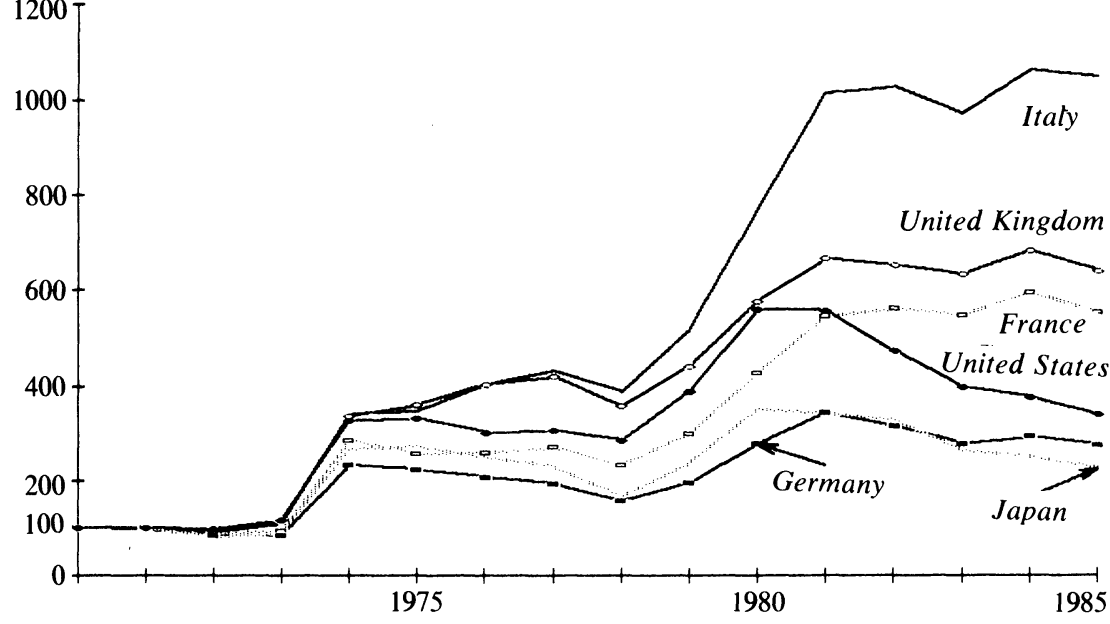

Sources: Author's calculations. Price from DOE, Annual Energy Review 1985, p. 135; and DOE, Monthly Energy Review, various issues. Converted to own currency using exchange rates from Organization for Economic Cooperation and Development, National Accounts of OECD Countries, 1962-79, 1971-83, and OECD, Quarterly National Accounts, number 3 (1985).

Because of changes in foreign exchange rates, the dollar-denominated price of crude oil does not necessarily reflect the true cost of imported oil to other countries. As figure A-1 shows, for France, Italy, and the United Kingdom, the 1981-85 decline in the dollar price of oil was offset by an appreciating dollar, so that their own-currency cost was unchanged. In Japan and Germany, the cost declined during 1981-85, but not by as much as the cost in dollars. The range of 1970-85 increases in own-currency cost of imported oil is striking: from a threefold increase for Japan and Germany to a tenfold increase for Italy.

Oil demand levels for the six countries since 1970 are shown in figure A-2. During 1960-73, oil demand increased sharply: by over 75 percent in the United States; more than twofold in the United Kingdom; more than threefold in France, Germany, and Italy; and nearly sevenfold in Japan. Since 1973, however, the six countries have experienced sub- 
Figure A-2. Oil Demand, Italy, United Kingdom, France, United States, Germany, and Japan, 1970-85

Demand index,

$1973=100$

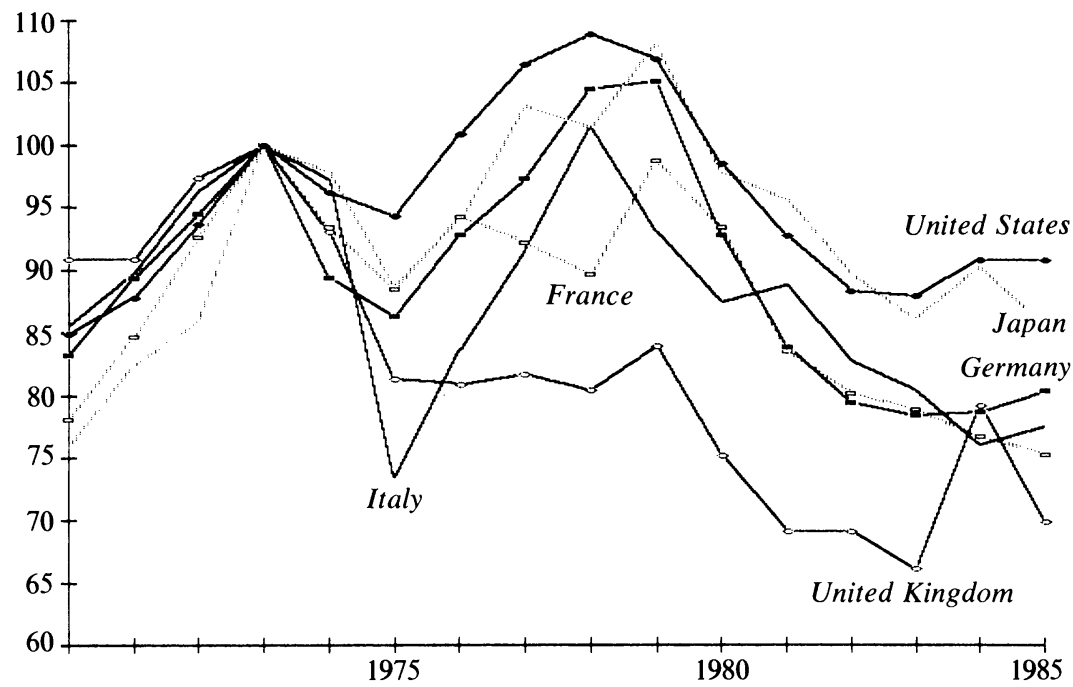

Source: Indexes constructed using data from DOE, Annual Energy Review 1985, p. 239; and DOE, Monthly Energy Review, various issues.

stantial declines: 30 percent in the United Kingdom; 20-25 percent in France, Germany, and Italy; 14 percent in Japan; and 10 percent in the United States. ${ }^{48}$

Table A-1 summarizes the results of the oil demand forecasts for each country. For France and Germany, oil demand projections for 1983-85 would have been on target if the correct assumptions had been made for price and GDP, but there would have been about a 10 percent overestimate if the constant price and higher GDP growth rates had been assumed. ${ }^{49}$ For the United Kingdom and for the United States, the two

48. Within the United States, when oil demand is disaggregated by product, most of the decline through 1985 has been in residual fuel, which is used by electric utilities. There have been much smaller declines in distillates (used for residential space heating) and other products. Transportation fuel demand in 1985 (gasoline and jet fuel) was almost as high as at its previous peak in 1978.

49. For Germany I assume that the 1982 actual level had been used as the base for the forecast, rather than the fitted level. 
Table A-1. 1982 Forecasts of 1985 Demand Using Two Alternative Assumptions Millions of barrels per day

\begin{tabular}{lccc}
\hline & & \multicolumn{2}{c}{ Forecast error } \\
\cline { 3 - 4 } \multicolumn{1}{c}{ Country } & $\begin{array}{c}\text { Actual demand } \\
\text { level }\end{array}$ & $\begin{array}{c}\text { Assuming actual } \\
\text { price and GDP } \\
\text { levels }\end{array}$ & $\begin{array}{c}\text { Assuming constant } \\
\text { price and higher } \\
\text { GDP }^{\mathrm{b}}\end{array}$ \\
\hline France & 1.82 & +0.02 & +0.17 \\
Germany & 2.35 & +0.11 & +0.22 \\
Italy & 1.67 & +0.22 & +0.54 \\
United Kingdom & 1.61 & +0.10 & +0.09 \\
Japan & 4.34 & -0.49 & +0.14 \\
United States & 15.70 & -0.03 & +0.02 \\
Total & 27.49 & -0.07 & +1.18 \\
\hline
\end{tabular}

Sources: U.S. Department of Energy, Monthly Energy Review, various issues, and author's forecast using the equations presented in table 1 .

a. Assuming that actual values for 1983-85 and own-currency price had been known in 1982 .

b. Assuming that 1983-85 own-currency price would be constant and that the 1983-85 GDP growth rates would be the same as $1976-79$ growth rates.

forecasts are basically the same and both are on target..$^{50}$ But for Italy the forecasts are not nearly as good: even with the correct assumptions, demand was overestimated by more than 10 percent; with the constant price and higher GDP growth rates, it would have been overestimated by over 30 percent. For Japan, however, the correct-assumption forecast underestimated the actual demand, while the constant-price-and-highergrowth forecast was close to actual demand.

50. For the United Kingdom the two sets of assumptions are basically the same. For the United States, however, declining oil prices and lower economic growth in 1983-85 apparently offset each other. 


\section{Comments and Discussion}

M. A. Adelman: Almost all energy models, including Dermot Gately's, share a basic theory of mineral economics: a limited stock must be allocated over time to maximize its present value. It follows that the price, net of extraction cost, must rise continuously at the prevailing rate of interest in order to compensate the holders and prevent arbitrage. Minerals in the ground are low-risk, appreciating assets.

The depletion process is strongly similar under competition and monopoly. Either way, the price trajectory is ever upward. Under some plausible assumptions, the competitive and monopoly patterns are identical, though Gately does not go that far.

Given the theory of mineral economics, the conclusions, both in Gately's paper and in the work of others, are logical. The pre-1973 price, and, in turn, the 1978 price, were unsustainably low. But the impressive consensus of an everlasting upcreep of minerals prices is in really striking contradiction to the facts. Over time, and with few or no exceptions, minerals prices have fallen, not risen. There is something very wrong with a premise of a fixed stock.

I suggest that minerals are inexhaustible or that mineral resources are nonbinding constraints. We will never get to the end of the deposits of oil, gas, coal, and other minerals. We will stop extracting any of them if and when the investment needed to create new inventories (proved reserves) exceeds their expected value. How much will then be left in the ground is unknowable and unimportant.

The economic problem is not with stocks but with the cost of providing flows: gross additions to reserves. But the models ignore incremental costs. The closest that the Gately paper comes is in referring to discovery size. In a given area under given conditions of knowledge, the odds are 
that we find the biggest fields first, even by chance, because they are biggest. And we exploit the cheapest first. Life is one long slide from good to bad and from bad to worse.

But diminishing returns have been offset, in fact more than offset, by increasing knowledge. Therefore, the marginal cost and the competitive market price of any mineral, including oil, is the uncertain fluctuating resultant of two strong opposing forces.

If we think in terms of flows, not stocks, three consequences follow. First, mineral production has at least normal risk. Assets do not normally appreciate. Second, if the 1973 pre-embargo price, and then, in turn, the pre-1979 price, had been unsustainably low, we should have seen a steep rise in marginal investment requirements in the OPEC countries before 1973 and continuing through at least 1979 . We see nothing of the kind.

One might try to rescue the proposition of increasing scarcity and untenable 1973 prices by invoking user cost, but user cost is simply the present value of the resource used up in production. Holding the asset for future sale is an investment. Development or exploration are alternative investments. Because they are all substitutes, the cost of each is a proxy for the others. Stable development costs, therefore, mean stable exploration and user cost.

The third consequence of thinking in terms of flows, not stocks, and of discarding the false paradigm of ever-rising prices is that the family resemblance between price and production trajectories under monopoly and under competition disappears. Inside OPEC, investment has shrunk radically. Outside OPEC, investment, capacity, and production have all expanded. Because supply depends on investment, any analysis whose key variable is percent of capacity utilized is, at most, of short-run significance. I think we ought to look separately at investment in two or two and one-half sectors.

First the monopoly sector, OPEC. Huge resources have been immobilized. There is enormous pent-up supply. My own calculations show a competitive floor of about $\$ 5$. At that price, the cartel countries could, within a decade, build up to over 60 million bpd capacity from currently proved reserves. They could stay there for another few years at least by expanding reserves in only the fields known today. What happens after that, nobody knows. The present value of a higher or lower price, past the year 2000, is not important. If the price stayed very low, say in the \$5-\$10 range, there would be an investment boom in the OPEC countries. 
The only way to save something from the wreck of the cartel would be for each producer to expand output. They would hate it, of course. And the fear of prices falling to $\$ 5$ may give them the energy of despair and renew the cartel.

Now consider the noncartel sector. They are at capacity, and Gately mentions the relatively brief "remaining life" of reserves in the United States and the North Sea. The United States in 1945 was more drilled up than is any other country today anywhere. Remaining reserves were 20 billion barrels. There were few large fields to be found. Over the next forty years, not twenty but one hundred billion barrels were produced in the United States, excluding Alaska, with sixteen billion barrels remaining at the end of 1985 . Furthermore, as far as I am aware, until 1973 , there was no increase in real cost.

This enormous reserve addition and depletion was no gift of nature, nor was it geologists' conservatism. Investment made the existing fields keep growing as they were exploited, and a great many small fields were discovered. So the notion of a country being at capacity and doomed to run down in the future omits the most basic fact-the inducement to invest to create reserves and capacity.

Contrary to Gately, expenditures outside of OPEC have created large reserve additions. They have been promptly, which is to say, efficiently, used up. But even outside the cartel, there are many areas where higher prices have a tendency to reduce investment, lower prices to increase investment.

Oil as an appreciating asset is a fiction, but belief in the fiction is a fact. During the 1970s, the higher the prices went, the higher they were expected to go. Noncartel governments thought they could benefit by withholding oil and gas for future production. Governments, therefore, demanded impossible terms from foreign oil companies. Others overtaxed or explicitly restrained production and exports. When oil prices declined after 1981, many reversed course, and production rose. It was no accident.

An outstanding example is Canada, which took a stunning capital loss of about 70 percent on the value of the asset exportable gas, which they are now promoting at much lower prices. The lesson is being learned all too slowly: government take is a rent and not a cost.

The notion of non-OPEC output eroding away, with prices in the 
range of $\$ 18$ to $\$ 22$, is illusory. Costs, excluding rents, are lower than that. Not even U.S. output would shrink appreciably, if at all. Output elsewhere would continue to expand.

Going now to the cartel nations: because they have short time horizons and high discount rates, they gravitate toward a policy of "take the money and run." They are too quick for their own good to raise prices and too slow for their own good to lower them. Relations are dominated by larger versus smaller. Small is beautiful. The small members cheat readily, knowing that the others will cover for them, but the buck stops with the largest. If he cheats, the agreement collapses. But he cannot afford to become everybody's favorite patsy; hence, the endless game of chicken: threats, then action to make the threats good.

History repeats itself, but with some significant differences. In January 1983 Saudi Arabia broke up an OPEC meeting. Within two months the rest of the cartel had agreed to quotas to which they adhered for a time. In November of 1985, the Saudis began to sell their full quota by discounting without limit, the so-called netback system. As in 1983, they got their way, but this time it took nine months, many meetings, and a price decline of 50 percent. The Saudis did gain because they had almost nothing to lose at the outset. One is tempted to say that another such victory and they are all finished, but I think not.

Where do we go from here? The cartel appears to have a perceived ceiling that is in the neighborhood, roughly, of $\$ 25$. If they can hold to the current level, some halfway between $\$ 5$ and $\$ 25$, they will try for more. "Market conditions" and OPEC "capacity utilization" are not important. Both times when prices exploded during the 1970s were periods of slack demand, except when production was deliberately cut to panic the market. Cohesion, or the lack thereof, is all-important.

The cartel is trying to control prices by the control of output. But short-run demand and supply are so inelastic that small output changes can yield big price changes. Small errors have big results. But the cartel managers do not even have current data. Production figures are often falsified. Consumption numbers lag by months in the industrial countries, by years in the less developed countries. Inventory data are shaky, even for the oil companies. Consumer stocks are a statistical black hole.

In success and failure alike, the cartel is clumsy and disruptive, but the lesson has been learned and the guilty secret is out: world oil can be 
monopolized and the rewards thereof are immense, so they will keep trying. I think the last thing we can possibly expect is smooth convergence to any supply-demand equilibrium.

James M. Griffin: Dermot Gately's analysis of the oil price collapse of 1986 offers assuring words to oil operators and public employees in the state of Texas. Take heart, OPEC is not dead. Gately's price forecasts suggest that the current price debacle is temporary and that by the year 2000 , oil prices will be in the $\$ 55$-to- $\$ 60$-a-barrel range (in 1985 dollars), an estimate that is similar to his 1982 forecast, appearing in the Energy Modeling Forum's survey of estimates of future oil prices. ${ }^{1}$ Further comfort is provided by William W. Hogan and Paul N. Leiby, who point out that at any time there exists a probability distribution of oil prices. Their analysis would suggest the 1986 price collapse was simply a lowprobability event that nevertheless occurred. Their mean oil price forecast for the year 2000 is almost $\$ 70$ a barrel. ${ }^{2}$

I would summarize Gately's paper as follows. The oil price collapse of 1986 is simply a large negative error term, causing us to revise upward the equations' standard error; otherwise, the underlying structural equations remain statistically valid, and the equations' forecast of even loftier peaks in oil prices in the distant future is still correct.

Before some of my wildcatting friends rush back into the oil patch and the Texas legislature relaxes upon learning that the state's $\$ 3.5$ billion deficit is only temporary, perhaps a bit more caution is in order. My purpose here is not to offer yet another oil price forecast but simply to examine the sensitivity of these conclusions to key underlying assumptions.

The conclusion that the current price decline is a temporary aberration rests on assumptions about the growth of world oil demand, non-OPEC supply, and the behavioral response of the OPEC cartel. Let us consider each in turn. Gately's analysis suggests that the sharp decline in world oil demand in 1980-82 and the stagnant growth thereafter were basically the result of lagged adjustments to oil price increases of the 1970s. Even though modest world gross domestic product growth from 1981 to 1985

1. Energy Modeling Forum, World Oil, EMF Report 6, Summary Report (Stanford, Calif.: EMF, February 1982).

2. William W. Hogan and Paul N. Leiby, "Risk Analysis with Energy Security Models" (Harvard University, John F. Kennedy School of Government, 1985). 
tended to increase oil demand, lagged price effects more than offset this tendency. With demand having fully adjusted to the price increases of the 1970s, a resumption in oil demand growth should be evident in the late 1980s and the 1990s as world GDP expands and the effects of the real price decline since 1981 are felt. While one might quibble about how robust this demand growth will be, depending on long-run price and income elasticities of demand, it seems clear that Gately's analysis is robust to a variety of plausible ranges for such elasticities.

Gately's assumption that non-OPEC production will soon peak and then begin to decline is plausible but subject to a good deal more uncertainty. Even if prices remain low, I am convinced that the shut-in of existing fields within the United States will not result in the large production losses estimated by various industry groups. ${ }^{3}$ Also, large gas reserves could enable the Soviets to expand oil exports by 3 to 4 million barrels a day by substituting natural gas for oil domestically. Particularly if oil prices stabilize at $\$ 20$ or more, Gately's conclusion may not hold. Rather than belabor such issues, let us move on to a more critical assumption.

With either constant or declining non-OPEC production, OPEC will be the sole beneficiary of a growing demand for oil. The behavioral assumption I would like to examine more closely is how growth in the demand for OPEC oil translates into oil price increases. It was Gately, Kyle, and Fischer who first argued that OPEC is likely to eschew dynamic wealth optimization models in favor of "rule of thumb" pricing. ${ }^{4}$ Because of its practicality, most models followed their suggestion and adapted simple price adjustment rules based on the degree of capacity utilization facing OPEC. Price determination in both Gately's model and in the Energy Information Agency model used by Hogan and Leiby adopts similar adjustment equations tied to the ratio of OPEC production to capacity. This feature is also embedded in nine of the ten models surveyed in the Energy Modeling Forum's comparison of world oil models. For the EMF analysis, OPEC capacity was held immutably at 34 million bpd—roughly equal to today's installed capacity. In Gately's

3. James M. Griffin and Clifton Jones, "Falling Oil Prices: Where is the Floor?" Energy Journal (forthcoming).

4. Dermot Gately, John Kyle, and Dietrich Fischer, "Strategies for OPEC's Pricing Decisions," European Economic Review, vol. 10 (November 1977), pp. 209-30. 
latest simulations, he projects OPEC capacity at both 25 million bpd and 35 million bpd.

With capacity assumed to be exogenously determined, demand for OPEC oil rises to capacity, and prices are allowed to increase sufficiently to hold production within this capacity constraint. The rate at which price then increases depends on short- and long-run price elasticities of non-OPEC supply, demand, and the elasticity of oil demand with respect to economic activity. Note that in Gately's figure 8, at one point or another prices begin rising sharply, ultimately reaching a $\$ 55$-to- $\$ 60$-abarrel price range by the year 2000. Given the capacity constraint, it is not surprising that models uniformly project real oil prices far in excess of the 1980 price peak.

It would seem that the most critical determinant of future oil prices is the exogenously determined OPEC capacity limits. Yet, little if any justification is given for such limits. In the EMF survey, 34 million bpd was chosen as capacity presumably because it coincided with 1981 installed capacity. But productive capacity has nothing to do with the constraints imposed by the underlying resource base. Known reserves in most OPEC countries would permit production rates many times current installed capacity: all that is needed is additional wells, pipelines, and loading terminals. In most OPEC countries, installed capacity is readily expandable because of the high potential production rates of individual wells. Morris Adelman has shown that at a marginal cost of $\$ 5$ a barrel, OPEC could expand productive capacity to 60 million bpd based entirely on known reserves. ${ }^{5}$ Because estimates of potential undiscovered reserves in these countries are quite large, such a rate could probably be sustained for a substantial period.

If current capacity in OPEC countries is not effectively constrained by the magnitude of the resource base, by technical limitations, or by costs of capacity expansion, then OPEC decisionmakers are truly unconstrained in their capacity choice. But if this is true, why should they choose to maintain productive capacity at 1970 levels? Admittedly, installed OPEC capacity has not changed appreciably over the past fifteen years, but is this sufficient justification for holding it fixed immutably for the next fifteen years? One could argue that over the past

5. M. A. Adelman, "The Competitive Floor to World Oil Prices," Energy Journal (forthcoming). 
fifteen years, OPEC countries had little reason to expand capacity. When production approached capacity, as in the late 1970s, OPEC countries simply raised prices instead of expanding capacity. At the time, there was little fear of driving price too high. Since then, falling demand has left OPEC production at only a fraction of capacity, providing little reason for expansion. But in the future as resumed demand growth pushes production up against existing capacity, will OPEC again choose to raise price rather than capacity as implied by the models of Gately and others? This amounts to assuming that the OPEC cartel will change very little both in membership and in behavioral characteristics.

I find such an assumption highly implausible. My own research indicates that OPEC is a partial market-sharing cartel rather than a dominant-firm type cartel in which one member, Saudi Arabia, or a few producers act as the residual supplier and other OPEC members behave competitively. ${ }^{6}$ With the exception of Iraq, Gabon, and Ecuador, OPEC members tend to raise and lower production jointly, with some members absorbing larger percentage production cuts than others. Because market-sharing behavior is the weakest type of cartel arrangement, the past may be little guide for the future. There are several reasons to expect intra-OPEC dissension.

First, the legitimacy of a cartel member's market share is likely to become blurred, especially after upheavals such as the Iran-Iraq war, the cessation of which will require a major reallocation of market shares if Iran and particularly Iraq, as is likely, expand production significantly.

Second, long-term interests among OPEC countries are varied. Small producers tend to prefer competitive behavior; those with huge resource bases prefer a low price-high output strategy. For example, many OPEC observers, including Gately, interpret the production increases by Saudi Arabia, Kuwait, and the United Arab Emirates in 1986 as a means of reducing price and disciplining cheaters within the cartel. As shown in my table 1, OPEC members have not shared equally in the drop in demand for OPEC crude following the 1979-80 price increases. Although statistical tests reject pooling of OPEC countries into behavioral groupings, it is often useful to think of OPEC as consisting of Output Maximizers, Price Maximizers, and the Cartel Core. ${ }^{7}$ As the table shows,

6. James M. Griffin, "OPEC Behavior: A Test of Alternative Hypotheses," American Economic Review, vol. 75 (December 1985), pp. 954-63.

7. Ibid. 
Table 1. Quarterly OPEC Production, 1980:1-86:2

Millions of barrels a day unless otherwise indicated

\begin{tabular}{|c|c|c|c|c|c|c|c|c|c|c|c|c|}
\hline \multirow[b]{2}{*}{ Country } & \multicolumn{4}{|c|}{1980} & \multicolumn{4}{|c|}{1981} & \multicolumn{4}{|c|}{1982} \\
\hline & 1 & 2 & 3 & 4 & 1 & 2 & 3 & 4 & 1 & 2 & 3 & 4 \\
\hline \multicolumn{13}{|c|}{ Output Maximizers } \\
\hline Iraq & 3.4 & 3.3 & 3.1 & 0.3 & 0.8 & 1.0 & 1.1 & 1.1 & 1.5 & 0.8 & 0.8 & 0.8 \\
\hline Nigeria & 2.2 & 2.1 & 1.9 & 2.0 & 1.9 & 1.4 & 0.9 & 1.6 & 1.4 & 1.3 & 1.2 & 1.4 \\
\hline Indonesia & 1.6 & 1.6 & 1.6 & 1.6 & 1.6 & 1.6 & 1.6 & 1.6 & 1.5 & 1.3 & 1.3 & 1.4 \\
\hline Ecuador & 0.2 & 0.2 & 0.2 & 0.2 & 0.2 & 0.2 & 0.2 & 0.2 & 0.2 & 0.2 & 0.2 & 0.2 \\
\hline Gabon & 0.2 & 0.2 & 0.2 & 0.2 & 0.2 & 0.2 & 0.2 & 0.2 & 0.2 & 0.2 & 0.2 & 0.2 \\
\hline Total & 7.6 & 7.4 & 7.0 & 4.3 & 4.7 & 4.4 & 4.0 & 4.7 & 4.8 & 3.8 & 3.7 & 4.0 \\
\hline \multicolumn{13}{|c|}{ Price Maximizer } \\
\hline Iran & 2.4 & 1.8 & 1.6 & 0.9 & 1.7 & 1.6 & 1.2 & 1.0 & 1.4 & 2.3 & 2.3 & 2.6 \\
\hline Algeria & 1.2 & 1.0 & 1.0 & 1.0 & 1.0 & 0.9 & 0.6 & 0.8 & 0.7 & 0.6 & 0.7 & 0.8 \\
\hline Venezuela & 2.2 & 2.1 & 2.2 & 2.3 & 2.2 & 2.1 & 1.9 & 2.2 & 1.9 & 1.5 & 1.9 & 2.3 \\
\hline Total & 5.8 & 4.9 & 4.8 & 4.2 & 4.9 & 4.6 & 3.7 & 4.0 & 4.0 & 4.4 & 4.9 & 5.7 \\
\hline \multicolumn{13}{|l|}{ Cartel Core } \\
\hline Saudi Arabia & 9.8 & 9.8 & 9.8 & 10.3 & 10.2 & 10.2 & 9.9 & 9.0 & 8.1 & 6.4 & 5.9 & 5.4 \\
\hline Kuwait & 2.2 & 1.6 & 1.4 & 1.6 & 1.6 & 1.0 & 1.0 & 0.9 & 0.8 & 0.8 & 0.9 & 0.9 \\
\hline Qatar & 0.5 & 0.5 & 0.5 & 0.5 & 0.5 & 0.4 & 0.4 & 0.4 & 0.4 & 0.3 & 0.3 & 0.3 \\
\hline UAE & 2.0 & 2.0 & 2.0 & 2.1 & 1.5 & 1.5 & 1.5 & 1.4 & 1.4 & 1.2 & 1.2 & 1.2 \\
\hline Libya & 2.1 & 1.7 & 1.7 & 1.7 & 1.6 & 1.4 & 0.7 & 0.9 & 0.7 & 0.8 & 1.3 & 1.7 \\
\hline Total & 16.6 & 15.6 & 15.4 & 16.2 & 15.4 & 14.5 & 13.5 & 12.6 & 11.4 & 9.5 & 9.6 & 9.5 \\
\hline Total OPEC & 30.0 & 27.9 & 27.2 & 24.7 & 25.0 & 23.5 & 21.2 & 21.3 & 20.2 & 17.7 & 18.2 & 19.2 \\
\hline
\end{tabular}

Source: Petroleum Intelligence Weekly, various issues.

the Core has borne the brunt of the production cutbacks. Comparing 1980 and 1985 production rates, we note that Ecuador and Gabon (both Output Maximizers) showed no tendency for restraint, while Nigeria, Indonesia, and Venezuela cut production by roughly 20 to 25 percent. The production changes in Iraq and Iran are largely determined by warrelated factors. Algeria, Qatar, the United Arab Emirates, and Libya cut production by about 40 percent, while Core members Kuwait and Saudi Arabia reduced output by 50 percent and 68 percent, respectively.

The smaller countries in OPEC have no doubt learned the benefits of making only marginal production cutbacks. Conversely, producers with huge reserve bases and relatively low production have no doubt realized that although the doubling of price in 1979-80 may have optimized the wealth of small OPEC producers, it did not optimize their own wealth. The quarterly production data in table 1 show that beginning in the fourth 
Table 1. (continued)

\begin{tabular}{|c|c|c|c|c|c|c|c|c|c|c|c|c|c|c|}
\hline \multicolumn{4}{|c|}{1983} & \multicolumn{4}{|c|}{1984} & \multicolumn{4}{|c|}{1985} & \multicolumn{2}{|c|}{1986} & \multirow{2}{*}{$\begin{array}{l}\text { Percent } \\
\text { change, } \\
1980-85\end{array}$} \\
\hline 1 & 2 & 3 & 4 & 1 & 2 & 3 & 4 & 1 & 2 & 3 & 4 & 1 & 2 & \\
\hline 0.8 & 1.0 & 1.0 & 1.1 & 1.1 & 1.2 & 1.3 & 1.3 & 1.3 & 1.3 & 1.5 & 1.7 & 1.7 & 1.7 & -42.6 \\
\hline 0.8 & 1.4 & 1.4 & 1.3 & 1.5 & 1.3 & 1.2 & 1.6 & 1.6 & 1.4 & 1.3 & 1.7 & 1.4 & 1.6 & -26.8 \\
\hline 1.1 & 1.4 & 1.4 & 1.5 & 1.5 & 1.5 & 1.4 & 1.4 & 1.3 & 1.2 & 1.3 & 1.3 & 1.3 & 1.4 & -20.3 \\
\hline 0.2 & 0.2 & 0.2 & 0.2 & 0.2 & 0.3 & 0.3 & 0.3 & 0.3 & 0.3 & 0.3 & 0.3 & 0.3 & 0.3 & +50.0 \\
\hline 0.2 & 0.2 & 0.2 & 0.2 & 0.2 & 0.2 & 0.2 & 0.2 & 0.2 & 0.2 & 0.2 & 0.2 & 0.2 & 0.2 & 0.0 \\
\hline 3.1 & 4.2 & 4.2 & 4.3 & 4.5 & 4.5 & 4.4 & 4.8 & 4.7 & 4.4 & 4.6 & 5.2 & 4.9 & 5.2 & -28.7 \\
\hline 2.5 & 2.3 & 2.7 & 2.4 & 2.3 & 2.0 & 2.0 & 2.3 & 2.1 & 2.2 & 2.4 & 2.3 & 2.0 & 2.1 & +34.3 \\
\hline 0.6 & 0.7 & 0.7 & 0.7 & 0.6 & 0.7 & 0.7 & 0.6 & 0.7 & 0.6 & 0.6 & 0.7 & 0.6 & 0.6 & -38.1 \\
\hline 2.0 & 1.7 & 1.7 & 1.8 & 1.8 & 1.8 & 1.8 & 1.8 & 1.7 & 1.7 & 1.7 & 1.7 & 1.7 & 1.7 & -22.7 \\
\hline 5.1 & 4.7 & 5.1 & 4.9 & 4.7 & 4.5 & 4.5 & 4.7 & 4.5 & 4.5 & 4.7 & 4.7 & 4.3 & 4.4 & -6.6 \\
\hline 4.0 & 4.2 & 5.6 & 5.7 & 4.8 & 5.0 & 4.3 & 3.7 & 3.6 & 2.7 & 2.5 & 4.1 & 4.3 & 4.7 & -67.5 \\
\hline 0.8 & 0.7 & 1.0 & 1.1 & 1.0 & 0.9 & 0.9 & 0.8 & 0.9 & 0.8 & 0.8 & 0.9 & 1.2 & 1.4 & -50.0 \\
\hline 0.2 & 0.3 & 0.3 & 0.4 & 0.4 & 0.4 & 0.4 & 0.3 & 0.3 & 0.3 & 0.3 & 0.3 & 0.4 & 0.3 & -40.0 \\
\hline 1.1 & 1.2 & 1.2 & 1.2 & 1.2 & 1.2 & 1.1 & 1.1 & 1.2 & 1.2 & 1.2 & 1.2 & 1.3 & 1.5 & -40.7 \\
\hline 1.0 & 1.1 & 1.2 & 1.2 & 1.1 & 1.2 & 1.0 & 1.0 & 1.0 & 1.0 & 1.0 & 1.2 & 1.0 & 1.1 & -41.6 \\
\hline 7.1 & 7.5 & 9.3 & 9.6 & 8.5 & 8.7 & 7.7 & 6.9 & 7.0 & 6.0 & 5.8 & 7.7 & 8.2 & 9.0 & \\
\hline 15.3 & 16.4 & 18.6 & 18.8 & 17.7 & 17.7 & 16.6 & 16.4 & 16.2 & 14.9 & 15.1 & 17.6 & 17.4 & 18.6 & -41.8 \\
\hline
\end{tabular}

quarter of 1985, Saudi Arabia and other members of the Core, excluding Libya, attempted to regain a market share merely in line with their earlier experience. The result was of course the price collapse of 1986. The Core countries were acutely aware that at the very low production rates of 1985 , the present value of their vast reserves was greatly diminished.

I disagree with Gately's conclusion that for price below $\$ 12$, output reductions by Saudi Arabia and other Core members would be irrational. Gately's claim is that with price above $\$ 12$ even the Saudis face an inelastic short-run demand and have incentives to cut production unilaterally, while with lower prices they lose revenue by cutting output further. But his conclusion overlooks both the game-theoretic aspect and the long-run elasticity of demand implications behind the Saudi strategy. To the contrary, I would argue that barring military intervention, the Saudi ploy was a no-lose gambit. If the price drop succeeded in 
eliminating cheating and reining in OPEC production, price could return to previous levels and enable Saudi Arabia and other Core producers to increase previous production rates. If the price drop failed to restore cartel discipline, price would remain relatively low and the Core, the holders of vast low-cost reserves, would be the primary beneficiaries of rapid demand growth in future years as a consequence of lower prices. In this latter scenario, it is easy to envision expansion of productive capacity to 20 million bpd in Saudi Arabia, another 7 million bpd in Kuwait, 6 million bpd in United Arab Emirates, and so on. With capacity expansions of this magnitude together with those in other OPEC countries, notably Iraq, it is possible to envision OPEC capacity of 40 or 50 million bpd. Under such a scenario, the sharp price increases to $\$ 55$ to $\$ 60$ a barrel (in 1985 dollars) by 2000 would not be sustainable.

All of this suggests that economic modeling approaches that arbitrarily set OPEC capacity are begging the question. Capacity expansions must be endogenized, and once they are, the results are likely to be quite sensitive to the factors determining capacity expansions.

Furthermore, much more attention must be given the changing behavioral responses within OPEC. The experience of the 1981 to 1986 period has underscored the considerable heterogeneity of interests among OPEC producers. Henry Steele likens OPEC to "an extended polygamous family . . . containing able patriarchs, propertied wives, a shrewd uncle or two, and a sprinkling of indolent brothers-in-law and other arrogant, elegant idlers." 8 Since relations in such a family are likely to be tumultuous, varying periodically from raptures to internecine warfare, I suspect that OPEC will continue to confound economic modelers.

\section{General Discussion}

Robert Pindyck suggested that the large drop in spot oil prices in the first half of 1986 could not be explained as simply the result of increased output by the Core group of OPEC producers. From 1979 to 1981, OPEC output decreased by 8 million bpd, largely as a result of the Iranian revolution and the Iran-Iraq war. At the same time, there was a massive sustained increase in worldwide inventories. As a consequence of both

8. James M. Griffin and H. B. Steele, Energy Economics and Policy, 2 d ed. (Academic Press, 1986). 
these developments, prices rose from $\$ 14$ to $\$ 32$ a barrel. In light of this experience, he found it implausible that the nearly 3 million bpd increase in Core output during the first half of 1986 could have caused prices to decline from $\$ 28$ to $\$ 14$. For one thing, Pindyck noted, the $\$ 28$ spot price at the end of 1985 is not a good benchmark from which to analyze the decline in prices. A better benchmark would be the December 1985 sixmonths-ahead futures price of $\$ 23$. He interpreted the unusual excess of spot prices over futures prices at that time as reflecting large convenience yields on holding inventories given relatively low inventory levels and the oncoming winter. But he reasoned that even a decline from $\$ 23$ to $\$ 14$ cannot be accounted for by just the Core group production increase of 3 million bpd. He cited three other causes of the oil price decline: an unusually warm winter in North America, lower-than-expected worldwide GNP growth, and greater-than-expected declines in LDC energy consumption.

William Nordhaus observed that one clear message of the paper and discussion was the importance of market structure assumptions for predicting the oil price path. The competitive price suggested by Adelman was somewhere in the range of $\$ 5$ to $\$ 10$ a barrel. A price between $\$ 10$ and $\$ 20$ might be the present-value maximizing price for the Core producers. And if the oil-producing countries simply pick a fixed quantity of output as appropriate, prices could be much higher. In considering future prices, Nordhaus argued the need to stress the inherent indeterminacy of oil prices in the medium run; they could be anywhere between $\$ 5$ and $\$ 100$ by the mid-1990s. That indeterminacy reflects the uncertainty about what market structure will prevail, together with very low shortrun demand and non-OPEC supply elasticities. Nordhaus concluded that we should expect tremendous volatility in oil prices in the coming years. In his view, the confidence band attached to most oil price projections is far too narrow.

Charles Holt suggested that institutional analysis of the actors involved in the oil market might yield better price projections than supply and demand analysis. Nordhaus added that some of the best analyses of the oil market during the 1970s and early 1980s were done by the CIA's Middle East experts.

Glenn Hubbard noted that while horizontal market structure is key to long-run price determination, vertical market structure has a significant influence on short-run price determination. The oil industry has moved 
from reliance on vertical integration and long-term contracts to reliance on short-term contracts and spot-market transactions. An active oil futures market has also developed. As a result, forecasts of short-run price paths now ought to take full account of the prices in futures markets. Philip Verleger estimated that spot trade currently accounts for between 50 and 75 percent of daily oil consumption, substantially eliminating arbitrage between markets. European and U.S. markets used to follow each other closely, but at one point last year, Verleger continued, Arab light oil was selling for $\$ 12$ on the U.S. Gulf Coast and for $\$ 20$ in Europe. Given high transportation costs, local price volatility attributable to short-run discrepancies in supply availability across markets will continue, absent changes in market structure. 